\title{
Association Mapping of Drought Avoidance and Agronomic Traits in Rice (Oryza Sativa L.) Landraces with SSR Markers and Genotyping-By- Sequencing Approach
}

\section{Beena R}

Kerala Agricultural University

Silvas Kirubakaran ( $\nabla$ silvas_jeba@yahoo.co.in )

Samuel Roberts Noble Foundation

Nithya $\mathbf{N}$

Kerala Agricultural University

\section{Sah R.P}

Central Rice Research Institute

\section{Abida P.S}

Kerala Agricultural University

\section{Sreekumar $\mathrm{J}$.}

Central Tuber Crops Research Institute

Jaslam M.P.K.

Chaudhary Charan Singh Haryana Agricultural University

\section{Rejeth R}

Kerala Agricultural University

Jayalekshmy V.G.

Kerala Agricultural University

\section{Roy S}

Kerala Agricultural University

\section{Manju R.V.}

Kerala Agricultural University

Viji M.M

Kerala Agricultural University

Manickavelu Alagu

Central University of Kerala

\section{Research Article}


Keywords: Development, physiological, root

Posted Date: December 18th, 2020

DOI: https://doi.org/10.21203/rs.3.rs-127517/v1

License: (c) (1) This work is licensed under a Creative Commons Attribution 4.0 International License. Read Full License 


\section{Abstract}

Development of rice varieties suited to varying drought stress level, and crop stages, relies mainly on identifying new genetic resources and genomic targets to improve whole plant physiological processes and productivity. This study with 99 rice germplasm adapted to Southwestern Indian peninsular region genotyped with 100 SSR markers evaluated over five different seasons/field trials to characterize plant physiological, root traits and yield related traits under different intensity and crop stage experienced water limitation. Traits like chlorophyll stability index, leaf rolling, days to $50 \%$ flowering, chlorophyll content, root volume and root biomass were identified as best predictors of grain yield under stress. Genome-Wide Association Study revealed genetic variation and genomic targets underlying major QTLs for different physiological, root and plant production traits. Combined analysis with trials 1-4 revealed 14 genomic regions governing multiple traits that contribute to plant performance and productivity under water stress. Genetic characterization of nine selected landraces and two elite cultivars using genotyping-bysequencing (GBS) revealed haplotype variation within genomic targets on chromosome 1, 4, 6 and 11 for potential use as molecular markers. The genetic and genomic resources identified will enable combining traits with agronomic value to optimize yield under stress and hasten trait introgression into elite cultivars.

\section{Introduction}

Globally, rice (Oryza sativa L.) is a staple food grown in 144 million hectares span across 114 countries

${ }^{1}$ to meet population explosion ${ }^{2}$. Global rice production was revolutionized after first green revolution with production increment of $140 \%$ by doubling of average productivity from 2.23 to $4.32 \mathrm{t} / \mathrm{ha}^{3}$. However, increased production of about $60 \%$ is expected to meet future global needs ${ }^{4}$. Indian rice production is estimated to be 148.26 million metric tons from land area of 44.1 million hectares, in which one-half area is irrigated ${ }^{5}$. Drought stress is one of the major threat to the rice production in the Asian-Pacific region, affects yield stability in rainfed ecosystems ${ }^{6}$. Development of drought-resistant rice cultivars is critical to reduce climate-related risk, maintain productivity, and enhance livelihood of rice growers ${ }^{7}$.

Drought tolerance consist of three major components involving interaction among physiological, morphological, biochemical traits ${ }^{8}$. The dehydration avoidance related traits maintain plant water status through enhanced root water uptake and reduced water loss in leaf through regulation of leaf area, stomatal conductance, canopy temperature and photosynthetic rate to result in high yield potential under water limitation. Leaf morphological, phenological, physiological and biochemical traits and their modulation is critical in maintaining plant water use and protect yield under water stress is well established in crop plants ${ }^{9-17}$. Roots are the first organ to experience water stress ${ }^{18}$ and strongly associated with grain yield under stress ${ }^{15,19,20}$. Later, root traits were viewed as target traits to improve drought adaptation ${ }^{21,22}$ and regulate the canopy temperature through stomatal regulation ${ }^{23}$. The increase in yielding potential was observed by introgression of root trait ${ }^{24}$. Number of studies have been done to establish the relevance of root traits for water uptake ${ }^{25-30}$ and their importance in yield 
protection under stress environments ${ }^{23,24,31}$. Efforts have been made to identify genomic regions associated with root traits in major cereal crops like rice ${ }^{32}$, wheat ${ }^{33}$ and legumes ${ }^{34-37}$. Drought adaptation and biomass productivity under stress depends on the plant Water Use Efficiency (WUE) or instantaneous Water Use Efficiency ${ }^{38-40}$.

The success in developing drought tolerant germplasm achieved so far is attributed through choice of parents, selection criteria, and robustness of the managed screening protocols ${ }^{41}$. The future genetic improvements in rice productivity will be achieved by adapting holistic approach that integrates plant breeding with physiological dissection of resistance traits and molecular genetic/genomic tools together with agronomical management practices. Alternative to conventional mapping approach, selective genotyping was successfully utilized in rice breeding to map major QTLs for secondary traits $10,13,25,42$ and grain yield under stress ${ }^{43}$. Most of these Quantitative trait Loci (QTLs) identified using bi-parental or multi-parental populations have limited the availability of allelic diversity and reduced genomic resolution for positional cloning process ${ }^{44-47}$. Genome Wide Association Study (GWAS) has emerged as a powerful approach to address limitations in traditional mapping approach and identify genes governing complex traits like rice root ${ }^{48-53}$ and production traits ${ }^{46,54-56}$. This approach has been successfully used to pinpoint root trait related genes associated with taproot cell length ${ }^{57}$ and cortex cell properties ${ }^{31}$.

To meet the global food demand, rich genetic diversity within both domestic and rice wild relatives should be explored towards genetic improvement of rice cultivars ${ }^{58-60}$. Brozynska et al. ${ }^{61}$ reviewed the importance of crop wild relatives as a contributor of novel alleles to improve food security and stress adaptation ${ }^{34,35,62-64}$. Genome comparison among 3010 diverse accessions from Asia ${ }^{65}$ exhibited huge divergence for novel alleles towards crop improvement. Local landraces and accessions from India are not widely represent in global rice panels ${ }^{66,67}$ in spite of useful genetic variation observed for various traits $10,12,13,24-26$. The rice cultivars/accessions adapted to Southern India needs to be explored to identify novel genetic and genomic targets to improve stress resilience as Tamil Nadu and Kerala, are key rice target environments, highly affected by water limitation ${ }^{12,14,24,27}$. The present study is conducted with the objectives (1) Screen diverse rice accession adapted to target environment drought stress adaptive plant physiology, root and water use efficiency traits (2) Estimate genetic diversity, population structure and identify marker-trait association and (4) Select parental genotypes with better phenotypic values towards developing rice cultivars with drought tolerance and productivity in water scarce environments.

\section{Materials And Methods}

Field evaluation of diverse panel for physiological and production traits (Trial 1 and 2)

\section{Genetic materials.}


Eighty-one diverse rice accessions (Panel 1) used for drought screening and identify marker trait association are listed in Supplementary Table 1. This panel includes indigenous land races (45 accessions) from and improved cultivar (36 varieties) from R.A.R.S., Pattambi, Kerala Agricultural University and National Rice Research Institute, Cuttack (ICAR-NRRI), Odisha. Most of the rice accessions were short and medium duration with red or white bold grain type with yield potential of 5-6t/ha, but with moderately tolerant or susceptible to abiotic stresses. Most of the landraces studied had an average yield potential of 2-3t/ha, tolerant to major pests and water stress.

\section{Experimental details:}

The experiment was conducted at Regional Agricultural Research Station, Pattambi, Kerala Agricultural University, India $\left(10^{\circ} 48^{\prime} 41.1^{\prime \prime} \mathrm{N} 76^{\circ} 11^{\prime} 24.9^{\prime \prime} \mathrm{E}\right)$, oldest rice research station in Kerala with managed irrigation facility for drought stress phenotyping studies. This experimental site is rice target environment and severely prone to heat and drought stresses. The selected diverse panel were grown in field site during wet season; Mundakan (August -December) of 2017 (Trial 1) and dry season; Puncha (January May), 2018 (Trial 2). The experiment was laid out in alpha lattice design with two replications in both control and irrigated treatments. In both seasons, wet (Trial 1) and dry (Trial 2), $10 \mathrm{~g}$ seeds of each genotype were planted in pots filled with soil, sand and cattle manure with equal v/v ratio. Twenty-one days old seedlings were transplanted to the open field at the rate of 2 seedlings/ hill. After 8 days of transplanting, gap filling was done and one healthy seedling was maintained per hill. Each genotype was transplanted in four rows of $2 \mathrm{~m}$ length with a spacing of $20 \times 15 \mathrm{~cm}$. Management practices were followed as per package of practices recommendation of Kerala Agricultural University. Fertilizer dose of N: P: K in the ratio of 90:45:45 Kg/ha in three split doses @ 1/3 dose of each fertilizer at basal, tillering and at panicle initiation stages. Blast incidence was controlled by using Nativo @ 4g/10 liters of water to impose water stress, irrigation was withheld for 25 consecutive days at the panicle initiation stage. Measurements on morphological and physiological parameters were recorded after 10 days of stress imposition. After stress period, re-watering was done at reproductive stage and maintained till physiological maturity. During harvest, data on plant production traits were recorded in both control and drought treatments. To quantify the soil moisture and the level of water stress data on moisture content was estimated using gravimetric method.

Physiological parameters such as leaf rolling score and drying score was done according to the Standard Evaluation System for Rice (SES) of IRRI, Philippines. Leaf rolling and drying scores were taken after 10 days of drought imposition as when leaf tissues showed drought symptoms during the time between $12 \mathrm{pm}$ and $1 \mathrm{pm}$. Leaf temperature was measured using infrared thermometer (AG-42, Teletemp Corporation, CA, USA) with an $8^{\circ}$ field of view and equipped with a 10.5 - to $12.5-\mu \mathrm{m}$ band pass filter, as described ${ }^{68}$. The measurement was made at noon by facing south to minimize the effects of sunlight. Cell membrane stability index was estimated as per the procedure described ${ }^{69}$. The relative leaf water content in percentage was measured based on the method described ${ }^{70}$. Total chlorophyll content was estimated by the method ${ }^{71}$ and from that chlorophyll stability index was calculated using formula. Chlorophyll stability index $(\%)=($ Total chlorophyll content at drought stress $/$ Total chlorophyll content at 
irrigated condition) $X 100$. Plant production traits like yield per plant was derived weighing filled grains in each panicle expressed in grams. Thousand-grain weight was measured from seeds selected randomly from each replication and weighed. Spikelet fertility (\%) was calculated as per standard formula, Spikelet fertility $(\%)=($ Number of fertile spikelet/ Total number of spikelets) $X 100$. Drought susceptibility index was measured according to Fisher and Maurer ${ }^{72}$. Percentage relative yield reduction (RYR) under stress was computed as per following equation: RYR $=1$ - (grain yield in drought stress / grain yield in irrigated condition) $\times 100$

\section{Evaluation of root architectural traits in diverse rice panel study (Trial 3 and 4)}

A previous study ${ }^{26}$ with another diverse panel of 81 accessions (Panel II) adapted to target environment adapted to rainfed environments (Supplementary Table 1). This panel includes medium duration rice landraces and improved varieties with average yielding potential of $2.5 \mathrm{t} / \mathrm{ha}$ (45) and 4-5 t/ha (36), respectively. Only 63 rice accessions are common across Panel I and II studied in different rice seasons prevalent in rice ecosystem of Kerala at the field with root phenotyping facility located. Rice seeds were planted in a specially constructed "root structure" of $5 \mathrm{ft} \times 10 \mathrm{ft} \times 60 \mathrm{ft}(\mathrm{H} \times \mathrm{W} \times \mathrm{L})$ during cropping season, Virippu (June -September) in 2011 and 2013. Five seeds per accessions were sowed in "root structure" which is located at $10^{\circ} 48^{\prime} 41.1^{\prime \prime} \mathrm{N} 76^{\circ} 11^{\prime} 24.9^{\prime \prime} \mathrm{E}$ within Regional Agricultural Research station (RARS), Pattambi, Kerala Agricultural University (KAU), India. Thinning was done on $18^{\text {th }}$ day and retained only one plant/hill. Each genotype were planted in a row of $2 \mathrm{~m}$ length with a spacing of $20 \times 15 \mathrm{~cm}$ and replicated twice. The crop was sole depend on rainfall as source of irrigation. Fertilizer dose of N:P:K in the ratio of $90: 45: 45 \mathrm{Kg} / \mathrm{ha}$ in three split doses @ 1/3 dose of each fertilizer at basal, tillering and at panicle initiation stages. Blast incidence was controlled by using Nativo@4g/10L water. After 60 days after planting (DAP) measurements on Specific leaf area (SLA) and SPAD measurement on chlorophyll content was made as detailed ${ }^{26}$. Seventy days after sowing root architectural traits were measured.

Five leaves from actively growing rice seedlings were collected for CID analysis fifty days after sowing. Fully opened leaves were dried in oven at $80^{\circ} \mathrm{C}$ for three days and powered the leaves using ball and mill. The water use efficiencies (WUE) of 81 rice accessions studied in the study was measured using $\Delta^{13} \mathrm{C}$ values, negatively associated with WUE. An isotope ratio mass spectrometer (IRMS) interfaced with a suitable combustion system is used for the determination of $\Delta^{13} \mathrm{C}$. The plants ability to discriminate against the heavy isotope of carbon $\left({ }^{13} \mathrm{C}\right)$, resulting in the depletion of ${ }^{13} \mathrm{C}$ content in biomass compared with atmospheric air during photosynthesis activity was used to measure $\mathrm{CID}^{73} . \Delta 13 \mathrm{C}$ was measured as the ratio of the partial pressures of $\mathrm{CO}_{2}$ inside the leaf to that in ambient air ( $\left.\mathrm{Pi} / \mathrm{Pa}\right)$, as follows: $\triangle 13 \mathrm{C}=\mathrm{a}$ $+(b-a) \mathrm{Pi} / \mathrm{Pa}$; where, $\mathrm{a}$ and $\mathrm{b}$ are isotope fractionations that occur during diffusion through stomata and carboxylation by Rubisco respectively.

SPAD (SPAD 502 plus chlorophyll meter, Spectrum Technologies, Inc.) was used to measure the chlorophyll content based on light absorbance and/or transmittance characteristics at 430nm and $750 \mathrm{~nm}$ on a leaf tissue. Percent chlorophyll content was measured between 10.00 and 16.00 hours on 
second or third fully expanded leaf lamina avoiding the mid-rib portion. Actual chlorophyll content was measured using lab based assay ${ }^{71}$. The specific leaf area (SLA) is measured as the ratio of leaf area to leaf dry weight, an indirect measure of leaf expansion as described ${ }^{26}$. Higher SLA phenotypic values represents larger leaf surface area available for transpiration, inversely related to WUE. Data on SLA was measured on completely expanded second or third leaf from main stem apex using a leaf area meter (Cl203, CID Bioscience, UK). Dry weight on the leaf used to measure SLA was collected after dried in a hotair oven at $70^{\circ} \mathrm{C}$ for three days and weighed. SLA was calculated as using the formula as below: SLA $\left(\mathrm{cm}^{-2} \mathrm{~g}^{-1}\right)=($ leaf area $/$ leaf dry weight)

After 70 days of planting data on plant height and biomass were collected. Then the brick wall in the root phenotyping structure were dismantled and strong jet of water was used to remove the excess soil adhering plant root system. The soil particles adhering close to rice roots were removed carefully and data on root length, root volume, root dry weight were measured as described ${ }^{26}$. Root length was manually measured using a ruler from shoot tiller-root junction to the deepest root. Root volume was measured in cubic centimeter by water displacement method, by immersing cleaned soil free roots into a measuring cylinder with 1 liter of water. Root dry weight was obtained from oven dried roots at $80^{\circ} \mathrm{C}$ for 48 hours.

\section{Effect of reproductive stress on rice agronomic traits (Trial 5)}

A subset of 35 diverse lines (Supplementary Table 1) within 81 diverse panels was evaluated under drought stress imposed on reproductive stage stress following a Completely Randomized Design in a rainout shelter of Department of Plant Physiology, College of Agriculture, Kerala Agricultural University during the year 2017. The subset genotypes were raised in polythene tubes of $25 \mathrm{~cm}$ diameter and $1 \mathrm{~m}$ height. Plants in both control and drought treatments were irrigated regularly until panicle initiation (PI) stage. After PI, irrigation was withheld for a period of 15 days in drought treatment PVCs to evaluate leaf, root and yield responses under reproductive stage water limitation. The control plants are irrigated regularly till maturity. The methodology used to quantify leaf-rolling response and root traits are published earlier ${ }^{27}$.

\section{Molecular Marker Genotyping:}

Leaf tissues of 20 days old plants on 81 diverse rice panel were collected in a small Ziploc bags in an ice cooler to extract genomic DNA. The leaf samples were stored at $-80^{\circ} \mathrm{C}$ until processed. Genomic DNA was extracted using the method by Dellaporta et al. ${ }^{74}$ and the quality of resultant DNA was determined using spectrophotometer (ELICO, SL 21 UV-Vis spectrophotometer) based on absorbance ratio of $260 \mathrm{~nm}$ to 280nm (A 260/A 280) between 1.7 and $1.8^{75}$. DNA quality was also assessed using gel electrophoresis with $5 \mu$ l of crude DNA sample on agarose gel $(0.8 \%)$ stained with ethidium bromide. A total of 100 SSR markers spanning whole rice genome across 12 chromosomes were selected from published rice literatures on drought tolerance (Supplementary Table 2). The genotyping was performed at College of Agricultural Vellayani, Thiruvannathapuram, Kerala Agricultural University (KAU), India. 
Gradient cycle was performed in Master Cycler gradient 5331 (Eppendorf version 2.30.31-09, Germany) to optimize the annealing temperature suitable for SSR genotyping in rice diverse panel. A final sample volume of $20 \mu \mathrm{l}$ was used for PCR reaction with reaction mixture contained $30 \mathrm{ng} / \mu \mathrm{l}$ DNA, $2.5 \mathrm{mM} \mathrm{dNTPs}$, $30 \mathrm{ng}$ forward and reverse primer each, 1 unit of Taq DNA polymerase with 10X reaction buffer and 25 $\mathrm{mM} \mathrm{MgCl} 2$. Genotyping was performed using the following PCR cycle: $94^{\circ} \mathrm{C}$ for $5 \mathrm{~min}(1 \mathrm{x}), 35 \mathrm{cycles}$ each of $94^{\circ} \mathrm{C}$ for $30 \mathrm{~s}, 50-60^{\circ} \mathrm{C}$ (vary depend on SSR annealing temperature) for $30 \mathrm{~s}, 72^{\circ} \mathrm{C}$ for 1 min with final cycle at $72^{\circ} \mathrm{C}$ for $5 \mathrm{~min}$ and $4^{\circ} \mathrm{C}$ for infinity. After PCR amplification, $3 \mu \mathrm{L}$ of gel loading dye (Bromophenol blue) was added directly to the reaction tubes and spun for few seconds in a micro centrifuge. The PCR amplicons were resolved on $2 \%$ agarose gel stained with ethidium bromide along with marker (100bp ladder). Electrophoresis (Bio-Rad, Deutsch) was performed using 1X TBE as buffer solution at 80 volts with running time of 90 minutes. The gel was visualized under UV $(312 \mathrm{~nm})$ transilluminator in gel documentation system (Syngene G-box documentation system) and scored as 1 for presence or 0 for absence of specific allele.

\section{Association mapping analysis}

Population structure of 81 rice genotypes was estimated using a STRUCTURE software V2.3.4 based on Bayesian clustering algorithm ${ }^{76}$. Five independent runs were made to detect the optimum number of subpopulations, with $K$ values ( $K=2$ to 8 ) using burn and run lengths of 50,000 . The results were imported to STRUCTUREHARVESTER software to calculate exact value of $1 \mathrm{~K}^{77}$. TASSEL 5 software package was used to calculate Linkage Disequilibrium (LD) for 81 diverse rice accessions at p-value < 0.05 . The analysis was conducted by considering genotypes with and without admixture identified by software STRUCTURE at K=2. The LD was estimated by considering the squared correlation coefficient

$\left(r^{2}\right)$ between SSR markers and plotted as triangle plots to evaluate LD blocks in association genetic analysis. The marker-trait association was calculated using TASSEL 5 based on General Linear Model (GLM) based on Q-matrix based on the population structure and a Mixed Linear Model based on Q-matrix and the kinship-matrix (MLM) ${ }^{78}$. In both models the markers with $p$-value $<0.05$ and $r^{2}$ value $>0.1$ were considered as significant markers for further analysis. To identify genes underlying major QTLs flanked by SSR markers, two-hundred Kb (both up and downstream) around the SSR marker physical positions were mined using Ricebase ${ }^{79}$ and QTL co-location across published literature were obtained from Rice SNP-Seek Database ${ }^{80}$. The tissue specific expression pattern of genes underlying QTLs were mined within rice Affymetrix and global transcriptome data integrated into Genevestigator software ${ }^{81}$.

\section{Genotype by Sequencing (GBS) of land races and elite varieties}

GBS data on eleven accessions of landraces and elite varieties, [PTB51 (Athira) and Jaya] used in this study were published recently as a part of in an effort to identify genome wide variant discovery in rice accessions $^{82}$. These accessions represent wide variety of rice taxa [PTB51 (Athira), PTB26 (Chenkayama), Chomala, Gandhakasala, Jaya, Jeerakasala, Kalladiyar, PTB2 (Ponnaryan), PTB8 (Thavalakannan), PTB10 (Thekkancheera) and PTB25 (Thonnuran)]. Accessions representing 
Oryzameyeriana subsp. Granulate from Wynad district: Chomala, Gandhakasala and PTB25 (Thonnuran) and PTB8 (Thavalakannan) from Kasarkode representing $O$. sativa f. spontanea (weedy rice) represents novel alleles that would improve grain yield and stress resilience in elite rice cultivars ${ }^{83}$. Each accession library was prepared after restriction digestion of 10-20 $\mu \mathrm{g}$ of genomic DNA by ApK1 + Pst1 enzyme followed by ligation of barcoded adapters. Library quality check was performed using Agilent Tape Station and sequenced on Illumina Nextseq 500 platform with $2 \times 150$ bp v2 chemistry. Further details on read depth and SNP calling can be obtained from previously published literature ${ }^{82}$.

\section{Statistical Analysis:}

The phenotyping data were analyzed statistically using the SAS program (SAS institute Inc., 1990). Principal component analysis, principal co-ordinate analysis and cluster analysis were done using $\mathrm{R}$ environment of statistical computing (R core Team, 2013). Predictors for leaf rolling and grain yield under stress were identified using bootstrap forest model integrated into JMP SAS software (v.15.1.0).

\section{Results}

\section{Phenotypic variation for morpho-physiological and plant production traits in Panel I}

Diverse rice accession within Panel I exhibited significant variation for morpho-physiological and plant production traits under water stress condition in trials 1 and 2 (Tables 1 and 2). The amount of precipitation and relative humidity observed in the trial sites are provided in Supplementary Figure 1 . The effect of water stress is evident in trial II with higher percent change in leaf temperature $\left(6^{\circ} \mathrm{C}\right)$ than trial 1 with $3^{\circ} \mathrm{C}$ resulted in reduction of plant height in trial $2(5.35 \%)$, in contrast to trial 1 with an average reduction of $4.58 \%$. Similar effect of water stress was observed for other production traits like days to $50 \%$ flowering, tiller number, yield per plant, and 1000-grain weight (Tables 1 and 2). Irrespective of the trials 1 and 2 under water stress treatment, PTB 7 produced higher tiller number with a range of 5 to 11 . The PTB55 and Prathyasha recorded the least and higher leaf rolling scores of 1.78 and 7.78 , respectively. In dry season of trial 2, the PTB 27 was found to maintain higher plant water status, which is evident with higher relative water content of 73 percent, than elite variety ADT37. PTB 35 recorded highest phenotypic values for yield per plant, 1000-grain weight through maintaining higher percent spikelet fertility traits in both trials. The relative yield reduction between rainfed and irrigated condition was lower in two accessions, Gopika and Shreyas with a reduction of 15 and 18 percent, respectively. These accessions also recorded lower drought susceptibility index of 1.14 and 1.17, whereas PTB 25 exhibited lower DSI across trials. The association between grain yield, physiological and plant production traits in trial 1 and 2 are detailed in Supplementary Tables 3 and 4.

\section{Phenotypic diversity for root traits and water use in panel II}

The rainfed treatment of trial 3 and 4 received a total precipitation of 61 and $75 \mathrm{~mm}$, respectively spanning a growth period of June through September (Supplementary Figure 1). In spite of lower precipitation in trial 3 , the diverse rice panel II exhibited higher average phenotypic value for $\mathrm{PH}(110.4$ 
$\mathrm{cm})$, shoot biomass $(19.3 \mathrm{~g})$ and root biomass $(12.6 \mathrm{~g})$. Whereas in trial 4 recorded average phenotypic value for $\mathrm{PH}(108 \mathrm{~cm})$, shoot biomass $(18 \mathrm{~g})$ and root biomass $(5.5 \mathrm{~g})$ (Table. 3 ). To account for variation in the agro climatic condition across years (Trial 3 and 4), average phenotypic values across trials were calculated. In trials 3-4, lower CID values were observed in accessions, PTB7, PTB4, PTB8 and Kalladiyar, lower SLA [PTB26, 8, 54, 10, Kalladiyar, Chomala], average higher PH [PTB2, 10, 6, PTB 24, Thottacheera, Jeerakasala], Higher RL and RV [PTB1,2, 8, 10, 15, Chovanan Modan, Kalladiyar], higher RB [PTB2, 10], and shoot biomass [PTB2, 10, 29), 26 and Kalladiyar]

\section{Relatedness among phenological, physiological and yield traits under stress}

In diverse panel I, the Principal Component Analysis (PCA) was performed for 14 morpho-physiological traits measured under water stress and well-watered conditions (Figure 1). In Trial 1 water stress, the PCA revealed two principal components with Eigen values $>2$ capturing $58.3 \%$ of the total variation. The plots for the Principal Component 1(PC1) vs. PC2 represented a higher phenotypic variation of 41.8 , and $14.6 \%$. PC1 was greatly influenced by traits relative water content, cell membrane stability index, chlorophyll stability index, yield, spikelet fertility percentage, drought susceptibility index, leaf rolling and leaf drying. In Trial 2, 2018 water stress, the PCA revealed two principal components with Eigen values $>1$ capturing $52.7 \%$ of the total variation. The plots for the Principal Component 1 (PC1) vs. PC2 represented a higher phenotypic variation of $35.8 \%$, and 16.9. In Trial 2, in addition to traits in Trial 1, plant height, tiller number, 1000-grain weight and relative yield ratio influenced PC1. Combining the data from trials 1 and 2 , revealed two principal components with Eigen values $>3$ capturing $50.6 \%$ of the total variation. The plots for the Principal Component 1 (PC1) vs. PC2 represented a higher phenotypic variation of $39.3 \%$, and 11.3. PC1 was greatly influenced by traits days to fifty percent flowering, drought susceptibility index, leaf temperature, spikelet fertility, relative water content and yield. Accessions

PTB1,4,12,15,17,19,26,28,34,35,37,40,52,55,60, Uma were found to have higher grain yield and spikelet fertility. The accessions, PTB 2,3,5,32,33,38,39,46,51,56,57, N-22, Sampada, Jeerakashala, Bhadra, Makom and Prathyasha were found to have alleles to improve DFF and DSI in rainfed condition.

To understand the relationship between significant phenological, physiological traits, root traits and shoot biomass measured in field trials 3 and 4, PCA was performed. The PCA revealed three principal components with Eigen values $>1$ capturing $60.6 \%$ of the total variation. The plots for the Principal Component 1(PC1) vs. PC2 represented a higher phenotypic variation (44.6\%), with 27.2 and $17.4 \%$, respectively. In 2011 study, PC1 was greatly influenced by traits SLA, RB, PH and SB. In 2013 study the PCA revealed three principal components with Eigen values $>1$ capturing $65.5 \%$ of the total variation. The plots for the Principal Component 1(PC1) vs. PC2 represented a higher phenotypic variation (52.0\%), with 35.6 and $16.4 \%$, respectively. Under both experimental conditions, the PC1 was greatly influenced by $\mathrm{PH}$ and SB whereas the PC2 is influenced by physiological and root traits. Correlation among average phenotypic values across years on $\mathrm{PH}, \mathrm{SDW}, \mathrm{RV}, \mathrm{RL}$ and RDW revealed plant height to be significantly associated with shoot biomass, root volume, and root biomass (Supplementary Table 5). The root traits, $\mathrm{RL}$ and $\mathrm{RV}$ are associated with both shoot and root biomass. The physiological traits, canopy 
temperature is positively correlated to plant height, negatively correlated to SPAD chlorophyll content and carbon isotope discrimination values measured

\section{Predictors of grain yield in different drought stress intensity}

Average data of 63 rice common accessions between trials 1 to 4 were used to identify traits that are good predictors of yield (Trial 1 and 2) and shoot biomass (Trials 3 and 4). The RWC, 1000GW, SF, CMS, $\mathrm{CSI}$ are determined to be best predictors of average grain yield in Trial 1 and 2 . Shoot biomass is directly associated with grain yield under rainfed rice ecosystems. The average data on RB, RV, SPAD (trials 3 and 4), LT and RYR (Trials 1 and 2) were best predictors of shoot biomass measured. To identify the grain yield predictors under different intensity of drought stress imposed on trials 1, 2 and 5, average data on 35 accessions common across trials were analyzed. This analysis revealed CSI (Trials 1 and 2), LR (trial 5), DFF (Trials 1 and 2), Chlorophyll content (Trial 2), RV (Trials 3 and 4) and RB (Trials 3 and 4) were found to best predictors of grain yield under water stress condition in trial 5 . Clustering of the 35 diverse accessions across trials 1-5 based on average RV and RB revealed 4 different clusters with four rice accessions [PTB1, 2,10 and 13] with higher average phenotypic value for RV and RB. Within this cluster, the accessions, PTB1,2, and 10 was found to be high yielding in trial 1-2, 4 and 5, also possess valuable alleles for root architectural traits. The average yield of PTB1 is $12 \mathrm{~g}$, whereas N22 rice cultivar is only 7.2 $\mathrm{g}$ in Trials 1-2, whereas in trial 5, the average shoot biomass of landrace, Ponnaryan (PTB2) across years is $27.6 \mathrm{~g}$, which is on par to rice hybrid, PHB71 (28.6g), and better than N22, a known rice cultivar to be drought and heat tolerant with $20.3 \mathrm{~g}$.

\section{Genotypic relatedness of diverse accession panels}

Genetic related analysis of Panel I revealed nine different clusters, including seven clusters only with local rice landraces harbor valuable alleles to improve different agronomic traits in rice lines adapted to rainfed ecosystem. Interestingly, Aryan (PTB1) and PTB10 (Thekkancheera) are genetically closer, whereas accession, PTB2 (Ponnaryan) is genetically dissimilar to any high yielding cultivars evaluated in this study. To illustrate the genetic relatedness among diverse rice lines of Panel II, Principal coordinate analysis (PCoA) was performed (Figure 2) reveled four quadrants with 56, 4, 8 and 13 genotypes, respectively. The fourth quadrant is a mixture with a pool of rice accessions with known drought tolerance [PTB30 (ChuvannaModan)], and other agronomic traits [PTB 20,33,34,47,56, Gandhakasala, Sampada,]. To gain more insights on the diversity and relatedness among diverse accessions, a hierarchical clustering was performed to derive a phylogenetic analysis representing seven clusters. Further mining of diverse accessions within in fourth quadrant, revealed PTB30 (Chuvanna Modan), PTB20 (Vadakkan Chitteni), PTB47 (Neeraja), PTB34 (Valiya Champan) are genetically similar than other accessions, Gandhakasala, PTB56 (Varsha), PTB33 (Arikkirai), and Sampada. PCA of marker data revealed a cluster with accession Ponnaryan with higher yield under stress and root architectural traits, is genetically similar to Vellari (Figure 3).

\section{Population structure and linkage disequilibrium analysis}


Population structure analysis among eighty-one rice genotypes with a set of 100 SSR markers determined optimum $\mathrm{K}$ value of two, representing the diverse panel group into two major clusters (Figure 4). In Panel I, first cluster comprised 65 genotypes and the second cluster with 16 genotypes including 6 admixture accessions. In Panel II, the first cluster comprised known to include drought susceptible genotypes but high yielding genotypes suited to irrigated condition, whereas the second cluster comprised known drought tolerant genotype, Nagina-22. Certain genotypes in cluster 2 had higher average phenotypic values across years than known drought tolerant genotype Nagina-22 for $\mathrm{PH}$ and SPAD [PTB28], RL [PTB1, 34 and Sabari), RV (genotypes in cluster 2), RB (PTB1) and SB (PTB60Vaishak).

The linkage disequilibrium (LD) map of the diverse panel (Panel I and II) revealed $8.25 \%$ of 100 SSR markers studied exhibited an $\mathrm{R}^{2}$ value of $\geq 0.1$. In Panel I, the LD was unevenly distributed at genome level and concentrated on chromosomes 1 and 5. Among 52 LD hotspots identified, includes 46 interchromosomal LD pairs and 6 intra chromosomal LD pairs. LD plots with SSR markers demonstrated significant LD blocks are shown in Figure 5. In Panel II, the LD was not uniform across the genome, higher LD values were observed on chromosomes $1,2,6$, and 9 with 49 LD pairs spanning genomic regions.

\section{Mapping genomic regions with association analysis}

The marker-trait associations for the phenotypic traits measured in diverse Panels I and II. In Panel I, the marker trait associations with GLM and MLM approaches identified 83 (Supplementary Table 6) and 16 (Table 4) significant loci, respectively. Especially the loci on chromosome 1, RM490 associated with CMS, CSI, RM259 associated with RWC, LR, LD, CMS, CSI, and SF identified with GLM approach, was identified by MLM approach. The loci, RM3825 on chromosome 1 associated with LT, RWC, CMS, CSI, Yield, 1000$\mathrm{GW}$, and SF (GLM) was detected in MLM approach with association with yield per plant.

In Panel II, the GLM approach detected 33 genomic regions associated with eight traits across genome except chromosomes 3 and 5 (Supplementary Table 7) with phenotypic variation ranging from 4.8 to 15.9 percent. The MLM approach detected 21 genomic regions (Table 5) associated with nine physiological and root architectural traits measured. Three new genomic regions that were not detected in GLM approach were identified with MLM approach. Three regions, RM283 (Chr.1), RM474 (Chr.10), RM5923 (Chr.11) were found only in MLM approach to be associated with SLA, SDW and RDW respectively. For example, the region RM1032 on chromosome 1 associated with plant height and root length, RM5961 on chromosome 11 was found to be associated with PH, CID and SLA.

\section{Tissue specific expression of genes underlying major QTL regions}

Based on the physical position of markers associated with key traits, genes underlying QTLs identified were tabulated (Table 6 and 7). In Panel I, eight loci on chromosomes 1, 4, 6, 9 and 11 flanking eleven genes were identified (Table 6). Among 11 genes, only 9 genes exhibited expression in Affymetrix datasets whereas all genes showed expression pattern in RNA-transcriptome. Among 13 genes identified in Panel II (Table 7), 10 genes exhibited tissue specific expression in rice grown in non-stress conditions. 
In Panel I, four genomic regions, RM490, RM3825 (chromosome 1), RM1130 and RM1031 (chromosome 6) were not detected in Panel II. The peptidase C45 gene (LOC_Os01g12230) associated with chlorophyll stability index was highly expressed in flag leaf in Affymetrix ${ }^{84}$ and transcriptome study ${ }^{85}$. Between two loci underlying genomic region RM3825, the Ras-related protein (LOC_Os01g62950) exhibited higher expression in pollen ${ }^{86}$ and anther ${ }^{87}$. The gene, DNA binding protein (LOC_Os06g45110) associated with RYR and DSI showed an higher expression in root tip ${ }^{88}$ specially in root elongation zone ${ }^{89}$. The expressed protein encoding gene, LOC_Os06g51330 exhibited higher expression of 14 fold in sperm cell ${ }^{86}$ and callus ${ }^{90}$.

Between Panel I and II, interestingly four locus (RM259, RM5633, RM1026 and RM5961) harboring five genes (LOC_Os01g13360, LOC_Os04g23030, LOC_Os04g23040, LOC_Os09g39320 and LOC_Os11g34070) were common and identified to be linked to key plant physiological production traits in rice. Gene expression analysis revealed the gene (LOC_Os01g09550) associated with SLA to be highly expressed in internode of rice dwarf mutant Fukei $71^{91}$, treatment with gibberellin ${ }^{92}$ and brassinosteroid $^{93}$. The loci RM259 associated with chlorophyll content underlying gene, LOC_Os01g13360 was found to highly expressed in endosperm ${ }^{94}$ and caryopsis ${ }^{95}$. The Loci, LOC_Os01g16400 associated with RL was found to highly expressed in root tip ${ }^{96}$ and LOC_Os01g16414 associated with $\mathrm{PH}$ was highly expressed in shoot apex ${ }^{95}$ and embryogenesis(PRJNA412710).The locus, LOC_Os04g23040 associated with SPAD, Chl, SLA on MLM approach was found to be highly expressed in flag leaves in both seedling and grain filling stages ${ }^{85,97}$ and leaf blade tissues ${ }^{92,98}$. LOC_Os08g01320 associated with RL, SPAD, Chl (GLM approach) and RL, CID (MLM approach) was found to highly expressed in flag leaf ${ }^{97}$, leaf blade (PRJNA392837) and root tissues (GSE24977). LOC_Os12g40460 associated with $\mathrm{RV}$ in both approaches were highly expressed in radicle tissue 99,100 .

Tissue specific expression data from global RNA transcriptome datasets revealed some genes not represented in Affymetrix arrays like, LOC_Os02g24205 associated with RV and SDW to be highly expressed in anther and pollen tissues ${ }^{87}$, LOC_Os07g33730 associated with RL expressed in callus tissues $^{90}$. The locus, LOC_Os09g39320 associated with chlorophyll content was found to highly expressed in flag leaf ${ }^{85}$. The genes, biotin-protein ligase (LOC_Os12g40450) and zinc finger, C3HC4 type domain protein (LOC_Os12g40460) associated with root volume was found to highly expressed in rice callus ${ }^{90}$ and embryo ${ }^{101}$.

\section{Genes underlying major QTL regions associated with drought stress}

In Panel I, analysis of 11 genes with stress transcriptome datasets revealed six genes (LOC_Os01g12230, LOC_Os01g62950, LOC_Os04g23040, LOC_Os06g45110, LOC_Os06g51330, LOC_Os09g39320) to be highly expressed in rice tissues. The LOC_Os01g12230 (CSI), LOC_Os04g23040 (DSI, RYR) and LOC_Os06g51330(SF) were highly expressed in leaf tissues under drought ${ }^{102}$. Intriguingly, the LOC_Os01g62950 (yield per plant), LOC_Os06g45110 (DSI and RYR) and LOC_Os09g39320 (LR, LD) were found to be highly expressed in four week old seedling root tissues under drought ${ }^{103}$. 
In Panel II, evaluation of rice stress related gene expression datasets revealed LOC_Os01g09550 and LOC_Os01g16414 associated with SLA and PH to highly express in leaf tissue and panicle under stress 104. These similar loci exhibited higher expression in rice root transcriptome study ${ }^{103}$ and in leaf tissues under drought (PRJNA306542). The locus, LOC_Os04g23040 associated with different leaf traits was found to highly expressed in flag leaf 105 and other leaves under drought $102,104,106$. LOC_Os08g01320 associated with above and below ground root traits were found highly expressed in both flag leaf and root tissues under drought 102,103,105-107. LOC_Os12g40460 associated with RV in both mapping approaches, showed higher expression in root tissues under drought ${ }^{108}$. Drought stress specific global RNA transcriptome datasets revealed certain genes like LOC_Os02g24205 to be highly expressed in leaf in drought stress studies in rice ${ }^{102,106}$. Whereas the locus, LOC_Os07g33730 associated with RL was found to be highly expressed in root tissues under drought ${ }^{103}$.The locus, LOC_Os09g39320 associated with root traits and chlorophyll content was found to highly expressed both roots and leaf tissues (Figure 6) under drought ${ }^{102,103,106}$. Among two genes near the locus RM5715, one gene, biotin--protein ligase (LOC_Os12g40450) associated with root volume showed higher expression in root tissues (Figure 6) under drought stress ${ }^{103}$.

\section{Gene targets and SNP haplotype variation for trait introgression}

Field trials in this study revealed 9 accessions with GBS data to have desired phenotypic variances in Trials 1-4 than two improved varieties [PTB51 and Jaya]. Comparing four field trials, PTB2 recorded higher CSI (trials 1 and 2), PH, RL, RV, RB and Shoot biomass (trials 3 and 4). PTB8 was identified to be possess higher phenotypic variation for grain yield, CSI (trials 1 and 2), whereas for PH, CID, SLA and Root traits (RL, RV) in trials 3 and 4. PTB10 also recorded lower LR and LD, higher 1000GW, and yield, whereas this accession exhibited lower SLA, PH, root traits (RL, RV and RB) and shoot biomass in trials 3 and 4. PTB25 recorded lower LR and LD, DSI values, higher $1000 \mathrm{GW}$ (trials 1 and 2) and higher shoot biomass (trials 3 and 4). In trials 1 and 2, PTB26 recorded higher SF and seed yield, whereas exhibited higher PH and shoot biomass in trials 3 and 4. Jeerakasala recorded lower RYR (trials 1 and 2) and higher PH (trials 3 and 4). Gandhakashala recorded lower DFF (trials 1 and 2) and CT than elite varieties, Jaya and PTB 51. Kalladiyar is an accession evaluated only in trials 3 and 4, found to have lower CID, lower SLA, higher RL and RV and shoot biomass.

Sequence level variation between Oryza sativa ssp. Indica reference genome to 93 local landraces from Kerala, revealed alternative haplotypes in key genomic regions identified in this study (Table 8). Further a deletion of sequence 'ACCATCCATC' ( $9318232 \mathrm{Mb}$ ) was found in all accessions evaluated in this study with single base pair, $C$ in contrast to reference genome. Further sequence level variation was compared between two elite varieties used (PTB51 and Jaya) with nine landraces studied (Table 9). The genomic region, around RM1032 on chromosome associated with $\mathrm{PH}$ and RL, reveled two SNPs different in PTB8 (Thavalakannan) than elite varieties. PTB8 (Thavalakannan) and Kalladiyar accessions also recorded lower SLA were found to have three different SNPs around RM5633 region (Table 9). PTB26 also found to harbor novel allele to improve SF (31089179 Mb) on chromosome 6 near RM1031 under water stress. 
Mining another genomic region on chromosome 11 associated with 1000GW revealed the accessionPTB25 (Thonnuran) to have allele similar to elite variety, PTB51, whereas other accessions PTB26 (Chenkayama) and Gandhakasala have novel alleles than elites for use as future breeding targets.

\section{Discussion}

Rice is a staple food for more than half of global population and South East Asia as a origin of rice with 88,681 different varieties which includes 55,615 landraces ${ }^{109}$. Rice land races are valuable genetic resources for improving agronomic traits, resilience and yield optimization under stress environments 61,62. Rice cultivation in Kerala, south-western corner of the Indian peninsular region dates back to 3000 B.C, holds valuable genetically diverse wild and cultivated rice accessions ${ }^{110}$. Recent efforts in rice breeding program enabled genetic improvement towards drought adaptation through conventional mapping approach ${ }^{12,14,111,112}$, marker assisted selection of high yielding varieties or by selection of secondary traits related to drought tolerance ${ }^{10,13,24,113}$. Wild crop relatives, wild/weedy species and primitive landraces are valuable genomic resources to identify new alleles for yield improvement in domesticated crop species ${ }^{114}$ are yet to be explored. Recently wild soybean was found to harbor novel alleles to enhance root system architecture and seed yield in cultivated soybean genetic backgrounds ${ }^{35,115-117}$.

The present study with two diverse panels, reveled valuable genetic resources to improve physiological processes and productivity in rainfed ecosystem. Combined phenotypic data across trials and panels revealed certain accessions as valuable genetic resources to increase shoot biomass [PTB10, PTB26], lower drought susceptibility index [PTB 25, Bhadra], and higher grain yield and spikelet fertility [PTB1, PTB60]. Certain accessions like PTB1, 2, 10, 13, 15, 29,30 were found as genetic resources to stack different traits to improve rice plant performance and yielding ability under drought with optimized root system. GWAS analysis revealed rice genomic region to be associated with phenological, physiological and root traits measured across seasons in this study. GWA studies in rice were successful in identifying genomic regions for agronomic ${ }^{118}$ and root traits $48,66,119$

Co-location of genomic regions identified in this study with previous rice QTL/association mapping studies are encouraging and are key candidate targets for introgression to develop next generation rice varieties drought tolerance. Seed yield under stress is a complex trait and a seamless benefit occurs out of coordinated activity of root and shoot physiological traits combined. Thus, identifying genomic regions that are associated with key physiological parameters and root traits are critical to optimize soil resources and improve yield under stress. Especially the genomic regions detected in Panel II with majority of rice landraces on chromosome 1 (RM246), 7 (RM1048), 9 (RM1026), and 12 (RM5715) governing both physiological and root structure under water limitation are valuable genomic targets for rice trait breeding approach. The RM246 QTL was found to be linked submergence ${ }^{120}$, salinity tolerance 121 , root biomass, basal root thickness ${ }^{122}$ and yield ${ }^{123,124}$. The RM1048 QTL was found to be linked with 
plant height ${ }^{125}$, panicle length ${ }^{126}$, leaf rolling ${ }^{127}$ and cold tolerance ${ }^{128}$. The common regions, RM1026

and RM5961 detected in both panels collocate QTLs for tiller number ${ }^{67}$, biomass and grain yield ${ }^{129}$, respectively.

Comparing two diverse panels, uncommon genomic targets between panels, Panel I (RM1031) and Panel II (RM0132 and RM5633) were selected. Mining of publically available transcriptome datasets reveled the gene, LOC_Os06g51330 underlying RM1031 region associated with SF will be an interesting target to increase seed setting under stress. The genes underlying Panel II specific targets (RM0132 and RM5633), LOC_Os01g16414 and LOC_Os04g23040 associated with plant height, leaf physiological and root architectural traits are valuable targets to improve rice productivity under stress. The accessions, PTB2 (Ponnaryan), PTB8 (Thavalakannan), PTB10 (Thekkancheera), PTB25 (Thonnuran), PTB26 (Chenkayama), PTB30(Chuvanna Modan), Gandhakashala, Jeerakasala and Kalladiyar are valuable genetic resources to combine different physiological, root architectural and seed yield to improve stress resilience and productivity in rainfed ecosystem. Key genomic targets identified on chromosome 1 (PH/RL), 4 (chlorophyll content/SLA), 6 (SF) and 11 (PH/CID/SLA/1000 GW) and their allelic variation in the genes underlying these QTLs are novel targets for use in rice drought breeding program. The SNPS identified in these key genomic targets are valuable and have potential to be developed as KASP markers to facilitate tracking and introgression of these target traits into elite rice cultivars suited to rainfed ecosystem.

\section{Declarations}

\section{Competing interests:}

The authors don't have any competing interest in publishing this article.

\section{Author's contributions:}

BR and SP Conceptualized the study. NN, BR, SP, SRP, SJ, MV assisted in data curation. AM provided SNP information on rice landraces used in this study. NN, SRP, SP, SJ, MV, JMPK, RR assisted in data analysis. BR, SP, MV, SRP, APS, RS, VMM, JVG provided the resources for research study. BR, APS, RS, VMM, JVG supervised the study and data collection. All authors reviewed and approved the manuscript. The datasets generated during and/or analysed during the current study are available from the corresponding authors on reasonable request.

\section{References}

1. FAO Rice Market Monitor, vol.XX(1), Rome, Itali (2017).

2. Uga, Y. et al. Control of root system architecture by DEEPER ROOTING 1 increases rice yield under drought conditions. Nature genetics 45, 1097-1102 (2013). 
3. Mohanty, N., Sekhar, M. R., Reddy, D. M. \& Sudhakar, P. Genetic variability and character association of agro-morphological and quality characters in rice. ORYZA-An International Journal on Rice 49, 88-92 (2012).

4. Bouman, B. A conceptual framework for the improvement of crop water productivity at different spatial scales. Agricultural systems 93, 43-60 (2007).

5. Pathak, H. et al. Rice Research for Enhancing Productivity, Profitability and Climate Resilience, ICARNational Rice Research Institute, Cuttack, Odisha, p 527 (2018).

6. Pandey, S. et al. Coping with drought in rice farming in Asia: insights from a cross-country comparative study. Agricultural Economics 37, 213-224 (2007).

7. Venuprasad, R. et al. Identification and characterization of large-effect quantitative trait loci for grain yield under lowland drought stress in rice using bulk-segregant analysis. Theoretical and Applied Genetics 120, 177-190 (2009).

8. Luo, L. J. Breeding for water-saving and drought-resistance rice (WDR) in China. Journal of Experimental Botany 61, 3509-3517, doi:10.1093/jxb/erq185 (2010).

9. Amudha, K. et al. Heterosis under aerobic condition in hybrid rice. Electronic Journal of Plant Breeding 1, 769-775 (2010).

10. Kanagaraj, P. et al. Microsatellite markers linked to drought resistance in rice (Oryza sativa L.). Current science, 98, 836-839 (2010).

11. Mutava, R. N. et al. Understanding abiotic stress tolerance mechanisms in soybean: a comparative evaluation of soybean response to drought and flooding stress. Plant Physiology and Biochemistry 86, 109-120 (2015).

12. Prince, S. J., Beena, R., Gomez, S. M., Senthivel, S. \& Babu, R. C. Mapping consistent rice (Oryza sativa L.) yield QTLs under drought stress in target rainfed environments. Rice 8, 25 (2015).

13. Salunkhe, A. S. et al. Fine mapping QTL for drought resistance traits in rice (Oryza sativa L.) using bulk segregant analysis. Molecular biotechnology 49, 90-95 (2011).

14. Suji, K. et al. Mapping QTLs for plant phenology and production traits using indica rice (Oryza sativa L.) lines adapted to rainfed environment. Molecular biotechnology 52, 151-160 (2012).

15. Babu, R. C. et al. Genetic analysis of drought resistance in rice by molecular markers: association between secondary traits and field performance. Crop Science 43, 1457-1469 (2003).

16. Vijaylakshmi D, Beena R, Vijaylakshmi, C. Heterosis for biochemical constituents and protein profiles of elite rice hybrids of Tamil Nadu. Biohelicon:Plant Physiology 1 (2a): 1-5 (2013).

17. Beena, R., Thandapani, V. \& Chandrababu, R. 2012a. Physio-morphological and biochemical characterization of selected recombinant inbred lines of rice for drought resistance. Indian Journal of Plant Physiology 17(2), 189-193 (2012a).

18. Prince, S. J., Mutava, R. N., Pegoraro, C., de Oliveira, A. C. \& Nguyen, H. T. in Genomics and breeding for climate-resilient crops 67-131 (Springer, 2013). 
19. Cairns, J., Audebert, A., Mullins, C. E. \& Price, A. H. Mapping quantitative trait loci associated with root growth in upland rice (Oryza sativa L.) exposed to soil water-deficit in fields with contrasting soil properties. Field Crops Research 114, 108-118 (2009).

20. Rong, L. Z. L. Z. Y. \& Ping, M. Study on Root Characters of Upland Rice and Paddy Rice (Oryza sativa L.). Journal of China Agricultural University, 1 (2002).

21. Gowda, V. R., Henry, A., Yamauchi, A., Shashidhar, H. \& Serraj, R. Root biology and genetic improvement for drought avoidance in rice. Field Crops Research 122, 1-13 (2011).

22. Kato, Y. \& Okami, M. Root morphology, hydraulic conductivity and plant water relations of highyielding rice grown under aerobic conditions. Annals of Botany 108, 575-583 (2011).

23. Prince, S. J. et al. Evaluation of high yielding soybean germplasm under water limitation. Journal of integrative plant biology 58, 475-491 (2016).

24. Suji, K. et al. Evaluation of rice (Oryza sativa L.) near iso-genic lines with root QTLs for plant production and root traits in rainfed target populations of environment. Field Crops Research 137, 89-96 (2012).

25. Beena, R., Praveenkumar, V., Vighneswaran, V. \& Narayankutty, M. Bulked line analysis: a useful tool to identify microsatellite markers linked to drought tolerance in rice. Indian Journal of Plant Physiology 23, 7-15 (2018).

26. Beena, R., Praveenkumar, V., Vighneswaran, V., Sindhumol, P. \& Narayankutty, M. Phenotyping for root traits and carbon isotope discrimination in rice genotypes of Kerala. ORYZA-An International Journal on Rice 54, 282-289 (2017).

27. Rejeth, R. et al. Water stress mediated root trait dynamics and identification of microsatellite markers associated with root traits in rice (Oryza sativa L.). Physiology and Molecular Biology of Plants 26, 1225-1236 (2020).

28. Prince, S. J. et al. Root xylem plasticity to improve water use and yield in water-stressed soybean. Journal of experimental botany 68, 2027-2036 (2017).

29. Manikanta, Ch.L.N. et al. A. Physio-morphological plasticity of rice (Oryza sativa L.) genotypes exposed to water stress. Journal of Tropical Agriculture 58(1): 139-145 (2020).

30. Naresh, B.P. et al. Morpho-physiological and proteomic analysis to identify and characterise the traditional rice genotypes for drought tolerance. Indian Journal of Plant Physiology. 23(4),785-795 (2018).

31. Prince, S. J. et al. Understanding genetic control of root system architecture in soybean: Insights into the genetic basis of lateral root number. Plant, cell \& environment 42, 212-229 (2019).

32. Courtois, B. et al. Rice root genetic architecture: meta-analysis from a drought QTL database. Rice 2, 115-128 (2009).

33. Soriano, J. M. \& Alvaro, F. Discovering consensus genomic regions in wheat for root-related traits by QTL meta-analysis. Scientific Reports 9, 10537 (2019). 
34. Manavalan, L. P. et al. Identification of novel QTL governing root architectural traits in an interspecific soybean population. PLoS One10, e0120490 (2015).

35. Prince, S. J. et al. Genetic variants in root architecture-related genes in a Glycine soja accession, a potential resource to improve cultivated soybean. BMC genomics 16, 132 (2015).

36. Prince, S. et al. in Plant and Animal Genome XXVI Conference (January 13-17, 2018). (PAG).

37. Monteros, M. J. et al. in ASA, CSSA and SSSA International Annual Meetings. (ASA, CSSA, and SSSA).

38. Ehdaie, B., Hall, A., Farquhar, G., Nguyen, H. \& Waines, J. Water-use efficiency and carbon isotope discrimination in wheat. Crop science 31, 1282-1288 (1991).

39. Zhao, B., Kondo, M., Maeda, M., Ozaki, Y. \& Zhang, J. Water-use efficiency and carbon isotope discrimination in two cultivars of upland rice during different developmental stages under three water regimes. Plant and Soil 261, 61-75 (2004).

40. Sheshshayee, M.S., Parsi, S.G., Madhura, J.N., Beena, R., Prasad, T.G. \& Udayakumar, M.Drought phenotyping in crops: from theory to practice. (Eds. Philippe Monneveux and Jean-Marcel Ribaut). CGIAR Generation Challenge Programme/ CIMMYT (2011).

41. Wassmann, R. et al. Climate change affecting rice production: the physiological and agronomic basis for possible adaptation strategies. Advances in agronomy 101, 59-122 (2009).

42. Beena, R., Sheshshayee, M.S., Madhura, J.N., Prasad, T.G. \& Udayakumar, M. Development of SSR markers and genetic variability in physiological traits in bambara groundnut (Vigna subterranea $\mathrm{L}$. Verdc). Prospects in Bioscience: Addressing the Issues. Springer Nature Publishing. (Eds Sabu,A and Anu A.). pp 229-242 (2012c).

43. Kumar, A. et al. Breeding high-yielding drought-tolerant rice: genetic variations and conventional and molecular approaches. Journal of experimental botany 65, 6265-6278 (2014).

44. Borevitz, J. O. \& Nordborg, M. The impact of genomics on the study of natural variation in Arabidopsis. Plant physiology 132, 718-725 (2003).

45. Korte, A. \& Farlow, A. The advantages and limitations of trait analysis with GWAS: a review. Plant methods 9, 1-9 (2013).

46. Swamy, B. M. et al. Association mapping of yield and yield-related traits under reproductive stage drought stress in rice (Oryza sativa L.). Rice 10, 21 (2017).

47. Beena, R. Studies on physio- morphological traits and genetic markers associated with drought responses in rice (Oryza sativa L.). Ph.D. thesis submitted to Tamil Nadu Agricultural University, Coimbatore, Tamil Nadu, India (2005).

48. Courtois, B. et al. Genome-wide association mapping of root traits in a japonica rice panel. PloS one 8, e78037 (2013).

49. Famoso, A. N. et al. Genetic architecture of aluminum tolerance in rice (Oryza sativa) determined through genome-wide association analysis and QTL mapping. PLoS Genet 7, e1002221 (2011).

50 . Huang, X. et al. Genome-wide association study of flowering time and grain yield traits in a worldwide collection of rice germplasm. Nature genetics 44, 32-39 (2012). 
51. Deshmukh, V. et al. Genome-wide consistent molecular markers associated with phenology, plant production and root traits in diverse rice (Oryza sativa L.) accessions under drought in rainfed target populations of the environment. Current Science 114, 329 (2018).

52. Raju, B. R. et al. Discovery of QTLs for water mining and water use efficiency traits in rice under water-limited condition through association mapping. Molecular Breeding 36, 35 (2016).

53. Verma, H., Borah, J. L. \& Sarma, R. N. Variability Assessment for Root and Drought Tolerance Traits and Genetic Diversity Analysis of Rice Germplasm using SSR Markers. Scientific Reports 9,16513 (2019).

54. Muthukumar, C., Subathra, T., Aiswarya, J., Gayathri, V. \& Babu, R. C. Comparative genome-wide association studies for plant production traits under drought in diverse rice (Oryza sativa L.) lines using SNP and SSR markers. Current science, 139-147 (2015).

55. Bhattarai, U. \& Subudhi, P. K. Genetic Diversity, Population Structure, and Marker-Trait Association for Drought Tolerance in US Rice Germplasm. Plants 8, 530 (2019).

56. Pradhan, S. K. et al. Linkage disequilibrium mapping for grain Fe and Zn enhancing QTLs useful for nutrient dense rice breeding. BMC Plant Biology 20, 57, doi:10.1186/s12870-020-2262-4 (2020).

57. Meijón, M., Satbhai, S. B., Tsuchimatsu, T. \& Busch, W. Genome-wide association study using cellular traits identifies a new regulator of root development in Arabidopsis. Nature genetics 46, 77 (2014).

58 . Huang, X. et al. A map of rice genome variation reveals the origin of cultivated rice. Nature 490, 497501 (2012).

59. Li, L.-F., Li, Y.-L., Jia, Y., Caicedo, A. L. \& Olsen, K. M. Signatures of adaptation in the weedy rice genome. Nature genetics 49, 811-814 (2017).

60. Wang, H., Vieira, F. G., Crawford, J. E., Chu, C. \& Nielsen, R. Asian wild rice is a hybrid swarm with extensive gene flow and feralization from domesticated rice. Genome research 27, 1029-1038 (2017).

61. Brozynska, M., Furtado, A. \& Henry, R. J. Genomics of crop wild relatives: expanding the gene pool for crop improvement. Plant biotechnology journal 14, 1070-1085 (2016).

62. Mammadov, J. et al. Wild relatives of maize, rice, cotton, and soybean: treasure troves for tolerance to biotic and abiotic stresses. Frontiers in plant science 9, 886 (2018).

63. Beena, R., An overview on QTLs linked to physio-morphological traits under water limited condition in rice (Oryza sativa L.). In: Advances in Plant Physiology, An International Treatise Series, Ed. Hemantaranjan A, Scientific Publishers 13:233-249 (2012b).

64. Santhanalakshmi, S., Shukla, K. \& Silvas Jeba Kumar Prince, K. Evaluation of resistance of wild rices, Oryza spp., to the whitebacked planthopper, Sogatella furcifera (Horvath)(Homoptera: Delphacidae). Archives Of Phytopathology And Plant Protection 43, 1088-1097 (2010).

65. Wang, W. et al. Genomic variation in 3,010 diverse accessions of Asian cultivated rice. Nature 557, 43-49 (2018). 
66. Li, X. et al. Genetic control of the root system in rice under normal and drought stress conditions by genome-wide association study. PLOS Genetics 13, e1006889 (2017).

67. Huang, X. et al. Genome-wide association studies of 14 agronomic traits in rice landraces. Nature genetics 42, 961 (2010).

68. Garrity, Dennis P., and John C. O'Toole. Selection for reproductive stage drought avoidance in rice, using infrared thermometry. Agronomy Journal 87 (4), 773-779 (1995).

69. Blum, A. and Adelina Ebercon. Cell membrane stability as a measure of drought and heat tolerance in wheat. Crop Science 21(1), 43-47 (1981).

70. Turner, N.C. Techniques and experimental approaches for the measurement of plant water status. Plant and soil 58, 339-366 (1981).

71. Hiscox, J. \& Israelstam, G. A method for the extraction of chlorophyll from leaf tissue without maceration. Canadian journal of botany 57, 1332-1334 (1979).

72. Fisher, R. A., and R. Maurer. Drought resistance in spring wheat cultivars. I. Grain yield responses in spring wheat. Australian Journal of Agricultural. Science 29, 892-912 (1978).

73. O'LEARY, M. Carbon isotope fractionation in plants, Photochem. 553-567 (1981).

74. Dellaporta, S., Wood, J. \& Hicks, J. A rapid method for DNA extraction from plant tissue. Plant Mol. Biol. Rep 1, 19-21 (1983).

75. Sambrook, J. \& Russell, D. Molecular Cloning, 3-Volume Set: A Laboratory Manual (Cold Spring Harbor, New York, USA: Cold Spring Harbor Laboratory Press, 2000).

76. Pritchard, J. K., Stephens, M. \& Donnelly, P. Inference of population structure using multilocus genotype data. Genetics 155, 945-959 (2000).

77. Earl, D. \& vonHoldt, B. Conservation Genet. 359-361 (2012).

78. Yu, J. \& Buckler, E. S. Genetic association mapping and genome organization of maize. Current opinion in biotechnology 17, 155-160 (2006).

79. Edwards, J. D., Baldo, A. M. \& Mueller, L. A. Ricebase: a breeding and genetics platform for rice, integrating individual molecular markers, pedigrees and whole-genome-based data. Database 2016, doi:10.1093/database/baw107 (2016).

80. Mansueto, L. et al. Rice SNP-seek database update: new SNPs, indels, and queries. Nucleic Acids Research 45, D1075-D1081 (2016).

81. Zimmermann, P. et al. ExpressionData-A public resource of high quality curated datasets representing gene expression across anatomy, development and experimental conditions. BioData mining 7, 1-11 (2014).

82. Vasumathy, S. K., Peringottillam, M., Sundaram, K. T., Kumar, S. H. K. \& Alagu, M. Genome- wide structural and functional variant discovery of rice landraces using genotyping by sequencing. Molecular Biology Reports 47, 7391-7402 (2020).

83. Latha, M., Abraham, Z., Nair, R. A., Mani, S. \& Dutta, M. Rice landraces of Kerala state of India: a documentation. International Journal of Biodiversity and Conservation 5, 250-263 (2013). 
84. Zhou, L. J., Xiao, L. T. \& Xue, H. W. Dynamic Cytology and Transcriptional Regulation of Rice Lamina Joint Development. Plant Physio/ 174, 1728-1746 (2017).

85. Lee, S. et al. Molecular bases for differential aging programs between flag and second leaves during grain-filling in rice. Sci Rep 7, 8792, (2017).

86. Russell, S. D. et al. Genomic profiling of rice sperm cell transcripts reveals conserved and distinct elements in the flowering plant male germ lineage. New Phytol 195, 560-573 (2012).

87. Sun, W. et al. The Rice Phytochrome Genes, PHYA and PHYB, Have Synergistic Effects on Anther Development and Pollen Viability. Sci Rep 7, 6439 (2017).

88. Norton, G. J., Aitkenhead, M. J., Khowaja, F. S., Whalley, W. R. \& Price, A. H. A bioinformatic and transcriptomic approach to identifying positional candidate genes without fine mapping: an example using rice root-growth QTLs. Genomics 92, 344-352 (2008).

89. Huang, L. \& Schiefelbein, J. Conserved Gene Expression Programs in Developing Roots from Diverse Plants. Plant Cell 27, 2119-2132 (2015).

90. Wu, Y. et al. Euchromatic subdomains in rice centromeres are associated with genes and transcription. Plant Cel/ 23 (2011).

91. Nakano, Y. et al. Transcription profiling identifies candidate genes for secondary cell wall formation and hydroxycinnamoyl-arabinoxylan biosynthesis in the rice internode. Plant Biotechnology 30, 433446 (2013).

92. Kudo, T. et al. UniVIO: a multiple omics database with hormonome and transcriptome data from rice. Plant Cell Physio/ 54, e9 (2013).

93. Liu, H., Yang, C. \& Li, L. Shade-induced stem elongation in rice seedlings: Implication of tissuespecific phytohormone regulation. J Integr Plant Bio/ 58, 614-617 (2016).

94. Li, M., Xu, W., Yang, W., Kong, Z. \& Xue, Y. Genome-wide gene expression profiling reveals conserved and novel molecular functions of the stigma in rice. Plant Physiol 144, 1797-1812, (2007).

95. Singh, A. K. et al. Genome-wide investigation and expression analysis of Sodium/Calcium exchanger gene family in rice and Arabidopsis. Rice 8, 54 (2015).

96. Gu, L. et al. Dissimilar Manifestation of Heterosis in Superhybrid Rice at Early-Tillering Stage under Nutrient-Deficient and Nutrient-Sufficient Condition. Plant Physio/ 172, 1142-1153 (2016).

97. Xu, W. et al. Transcriptome phase distribution analysis reveals diurnal regulated biological processes and key pathways in rice flag leaves and seedling leaves. PLoS One 6, e17613 (2011).

98. Fujita, M. et al. Rice expression atlas in reproductive development. Plant Cell Physio/ 51, 2060-2081 (2010).

99. Xing, M. Q. et al. Global Analysis Reveals the Crucial Roles of DNA Methylation during Rice Seed Development. Plant Physiol 168, 1417-1432 (2015).

100. Ouyang, Y., Huang, X., Lu, Z. \& Yao, J. Genomic survey, expression profile and co-expression network analysis of OsWD40 family in rice. BMC Genomics 13, 100 (2012). 
101. Narsai, R. et al. Dynamic and rapid changes in the transcriptome and epigenome during germination and in developing rice (Oryza sativa) coleoptiles under anoxia and re-oxygenation. Plant $J$ 89, 805824 (2017).

102. Galbiati, F. et al. Hd3a, RFT1 and Ehd1 integrate photoperiodic and drought stress signals to delay the floral transition in rice. Plant Cell Environ 39, 1982-1993 (2016).

103. Yoo, Y. H. et al. OsPhyB-Mediating Novel Regulatory Pathway for Drought Tolerance in Rice Root Identified by a Global RNA-Seq Transcriptome Analysis of Rice Genes in Response to Water Deficiencies. Front Plant Sci 8, 580 (2017).

104. Krishnan, A., Gupta, C., Ambavaram, M. M. R. \& Pereira, A. RECoN: Rice Environment Coexpression Network for Systems Level Analysis of Abiotic-Stress Response. Front Plant Sci 8, 1640 (2017).

105. Ding, X., Li, X. \& Xiong, L. Insight into differential responses of upland and paddy rice to drought stress by comparative expression profiling analysis. Int J Mol Sci 14, 5214-5238 (2013).

106. Huang, L. et al. Comparative transcriptome sequencing of tolerant rice introgression line and its parents in response to drought stress. BMC Genomics 15, 1026 (2014).

107. Fu, J. et al. OsJAZ1 Attenuates Drought Resistance by Regulating JA and ABA Signaling in Rice. Front Plant Sci 8, 2108 (2017).

108. Wang, D. et al. Genome-wide temporal-spatial gene expression profiling of drought responsiveness in rice. BMC Genomics 12, 149 (2011).

109. Mishra, P. \& Sinha, A. K. Rice diversity in bankura district of West bengal (India). Bioscience discovery 3, 284-287 (2012).

110. Manilal, K. Ethnobotany of the rices of Malabar. Contribution to Indian Ethnobotany, 243-253 (1990).

111. Sellamuthu, R., Liu, G. F., Ranganathan, C. B. \& Serraj, R. Genetic analysis and validation of quantitative trait loci associated with reproductive-growth traits and grain yield under drought stress in a doubled haploid line population of rice (Oryza sativa L.). Field Crops Research 124, 46-58 (2011).

112. Gomez, S. M. et al. Molecular mapping and location of QTLs for drought-resistance traits in indica rice (Oryza sativa L.) lines adapted to target environments. Acta physiologiae plantarum $32,355-$ 364 (2010).

113. Pradeepa, N. et al. In Silico analysis of a consensus QTL for drought resistance in rice. Online $J$ Bioinformatics 13, 1-13 (2012).

114. Tanksley, S. D. \& McCouch, S. R. Seed banks and molecular maps: unlocking genetic potential from the wild. science 277, 1063-1066 (1997).

115. Prince, S. J. et al. Mapping Quantitative Trait Loci for Soybean Seedling Shoot and Root Architecture Traits in an Inter-Specific Genetic Population. Frontiers in Plant Science 11, 1284 (2020).

116. McNeece, B. T., Bagherzadi, L., Carter Jr., T. E. \& Mian, M. A. R. Registration of USDA-N7004 soybean germplasm with good yield, elevated seed protein, and $25 \%$ exotic pedigree from Tamahikari. Journal 
of Plant Registrations n/a, doi:10.1002/plr2.20039.

117. Liang, H. et al. Inheritance and QTL mapping of related root traits in soybean at the seedling stage. Theoretical and applied genetics 127, 2127-2137 (2014).

118. Zhao, K. et al. Genome-wide association mapping reveals a rich genetic architecture of complex traits in Oryza sativa. Nature communications 2, 1-10 (2011).

119. Phung, N. T. P. et al. Genome-wide association mapping for root traits in a panel of rice accessions from Vietnam. BMC plant biology 16, 64 (2016).

120. Sripongpangkul, K. et al. Genes/QTLs affecting flood tolerance in rice. Theoretical and Applied Genetics101, 1074-1081 (2000).

121. Koyama, M. L., Levesley, A., Koebner, R. M. D., Flowers, T. J. \& Yeo, A. R. Quantitative Trait Loci for Component Physiological Traits Determining Salt Tolerance in Rice. Plant Physiology 125, 406-422 (2001).

122. Li, Z. et al. QTL mapping of root traits in a doubled haploid population from a cross between upland and lowland japonica rice in three environments. Theoretical and Applied Genetics 110, 1244-1252 (2005).

123. Luo, L. J. et al. Overdominant Epistatic Loci Are the Primary Genetic Basis of Inbreeding Depression and Heterosis in Rice. II. Grain Yield Components. Genetics 158, 1755-1771 (2001).

124. Cho, Y. G. et al. Identification of quantitative trait loci in rice for yield, yield components, and agronomic traits across years and locations. Crop Science 47, 2403-2417 (2007).

125. Zenbo, T. et al. Identification of QTLs for lengthes of the top internodes and other traits in rice and analysis of their genetic effects. Yi Chuan xue bao Acta Genetica Sinica 23, 439-446 (1996).

126. Yoshimura, A., Takano-Kai, N. \& Anno, C. Linkage mapping of genes for short panicle and awn in rice. Rice Genetics Newsletter 21, 17-19 (2004).

127. Xu, J., Zhong, D., Yu, S., Luo, L. \& Li, Z. QTLs affecting leaf rolling and folding in rice. Rice Genetics Newsletter 16, 51-53 (1999).

128. Hou, M.-Y. et al. Inheritance and QTL mapping of low temperature germinability in rice (Oryza sativa L.). Acta Genet Sin 31, 701-706 (2004).

129. Bhandari, A. et al. Genome-wide association study for yield and yield related traits under reproductive stage drought in a diverse indica-aus rice panel. (2020).

\section{Tables}


Table 1

Descriptive analysis of phenotypic, physiological and yield traits measured in Trial 1

\begin{tabular}{|c|c|c|c|c|c|c|}
\hline \multirow[t]{2}{*}{ Traits } & \multicolumn{2}{|l|}{ Mean } & \multicolumn{2}{|l|}{ Range } & \multirow{2}{*}{$\begin{array}{l}\text { Percentage } \\
\text { change }\end{array}$} & \multirow[t]{2}{*}{ P-value } \\
\hline & WS & C & WS & $\mathrm{C}$ & & \\
\hline Plant height (cm) & $\begin{array}{l}110.74 \\
\pm 12.71\end{array}$ & $\begin{array}{l}116.05 \pm \\
12.78\end{array}$ & $\begin{array}{l}82.50- \\
135.00\end{array}$ & $\begin{array}{l}87.50- \\
144.10\end{array}$ & -4.58 & 0.000251774 \\
\hline Tiller number & $\begin{array}{l}7.53 \pm \\
1.22\end{array}$ & $\begin{array}{l}10.25 \pm \\
1.39\end{array}$ & $\begin{array}{l}5.00- \\
11.00\end{array}$ & $\begin{array}{l}7.00- \\
14.00\end{array}$ & -26.54 & $2.04 \mathrm{E}-41$ \\
\hline $\begin{array}{l}\text { Days to } 50 \% \\
\text { flowering }\end{array}$ & $\begin{array}{l}94.65 \pm \\
10.01\end{array}$ & $\begin{array}{l}88.47 \pm \\
10.81\end{array}$ & $\begin{array}{l}67.50- \\
119.00\end{array}$ & $\begin{array}{l}61.50- \\
114\end{array}$ & 6.99 & $3.8 \mathrm{E}-07$ \\
\hline $\begin{array}{l}\text { Leaf temperature } \\
\left({ }^{\circ} \mathrm{C}\right)\end{array}$ & $\begin{array}{l}28.26 \pm \\
0.589\end{array}$ & $\begin{array}{l}27.50 \pm \\
0.533\end{array}$ & $\begin{array}{l}26.95- \\
29.00\end{array}$ & $\begin{array}{l}26.00- \\
29.35\end{array}$ & 2.76 & $3.16 \mathrm{E}-27$ \\
\hline Leaf rolling score & $\begin{array}{l}4.80 \pm \\
1.38\end{array}$ & - & $\begin{array}{l}1.78- \\
7.78\end{array}$ & - & - & \\
\hline Leaf drying score & 1.93 & - & $\begin{array}{l}1.56- \\
9.00\end{array}$ & - & - & \\
\hline $\begin{array}{l}\text { Relative water } \\
\text { content (\%) }\end{array}$ & $\begin{array}{l}65.19 \pm \\
4.78\end{array}$ & $\begin{array}{l}84.13 \pm \\
3.22\end{array}$ & $\begin{array}{l}57.34- \\
78.72\end{array}$ & $\begin{array}{l}75.70- \\
90.17\end{array}$ & -22.51 & 1.3E-127 \\
\hline $\begin{array}{l}\text { Cell membrane } \\
\text { stability index (\%) }\end{array}$ & $\begin{array}{l}84.95 \pm \\
3.72\end{array}$ & - & $\begin{array}{l}80.28- \\
94.36\end{array}$ & - & - & - \\
\hline $\begin{array}{l}\text { Chlorophyll stability } \\
\text { index (\%) }\end{array}$ & $\begin{array}{l}86.14 \pm \\
3.57\end{array}$ & - & $\begin{array}{l}80.36- \\
95.59\end{array}$ & - & - & - \\
\hline Yield/plant (g) & $\begin{array}{l}9.55 \pm \\
1.89\end{array}$ & $\begin{array}{l}12.94 \pm \\
2.38\end{array}$ & $\begin{array}{l}6.55- \\
14.47\end{array}$ & $\begin{array}{l}8.33- \\
19.64\end{array}$ & -26.20 & $1.05 \mathrm{E}-34$ \\
\hline $\begin{array}{l}\text { Thousand grain } \\
\text { weight }(\mathrm{g})\end{array}$ & $\begin{array}{l}22.71 \pm \\
1.48\end{array}$ & $\begin{array}{l}23.55 \pm \\
1.41\end{array}$ & $\begin{array}{l}17.55- \\
25.35\end{array}$ & $\begin{array}{l}18.70- \\
25.95\end{array}$ & -3.57 & $5.71 \mathrm{E}-07$ \\
\hline $\begin{array}{l}\text { Spikelet fertility } \\
\text { percentage }(\%)\end{array}$ & $\begin{array}{l}65.26 \pm \\
4.58\end{array}$ & $\begin{array}{l}75.43 \pm \\
4.75\end{array}$ & $\begin{array}{l}54.19- \\
78.22\end{array}$ & $\begin{array}{l}64.96- \\
86.91\end{array}$ & -13.48 & $2 \mathrm{E}-55$ \\
\hline $\begin{array}{l}\text { Percentage relative } \\
\text { yield reduction }\end{array}$ & $\begin{array}{l}25.48 \pm \\
4.64\end{array}$ & - & $\begin{array}{l}14.84- \\
43.81\end{array}$ & - & - & - \\
\hline $\begin{array}{l}\text { Drought } \\
\text { susceptibility index }\end{array}$ & $\begin{array}{l}1.00 \pm \\
0.062\end{array}$ & - & $\begin{array}{l}0.86- \\
1.14\end{array}$ & - & - & - \\
\hline Soil moisture (\%) & - & - & $\begin{array}{l}12.4- \\
30.96\end{array}$ & - & - & - \\
\hline
\end{tabular}


Table 2

Descriptive analysis of phenotypic, physiological and yield traits measured in Trial 2

\begin{tabular}{|c|c|c|c|c|c|c|}
\hline \multirow[t]{2}{*}{ Traits } & \multicolumn{2}{|l|}{ Mean } & \multicolumn{2}{|l|}{ Range } & \multirow{2}{*}{$\begin{array}{l}\text { Percentage } \\
\text { change }\end{array}$} & \multirow{2}{*}{$\begin{array}{l}\mathrm{P} \text { - } \\
\text { value }\end{array}$} \\
\hline & WS & C & WS & C & & \\
\hline Plant height $(\mathrm{cm})$ & $\begin{array}{l}106.28 \pm \\
12.56\end{array}$ & $\begin{array}{l}112.29 \pm \\
12.28\end{array}$ & $\begin{array}{l}80.15- \\
130\end{array}$ & $\begin{array}{l}86.50- \\
140.50\end{array}$ & -5.35 & $\begin{array}{l}2.12 \mathrm{E} \\
05\end{array}$ \\
\hline Tiller number & $\begin{array}{l}6.34 \pm \\
0.845\end{array}$ & $\begin{array}{l}8.88 \pm \\
1.23\end{array}$ & $\begin{array}{l}5.00- \\
8.50\end{array}$ & $\begin{array}{l}6.50- \\
13.00\end{array}$ & -28.60 & $\begin{array}{l}7.87 \mathrm{E} \\
52\end{array}$ \\
\hline Days to $50 \%$ flowering & $\begin{array}{l}91.26 \pm \\
10.86\end{array}$ & $\begin{array}{l}85.78 \pm \\
10.36\end{array}$ & $\begin{array}{l}65.50- \\
115.50\end{array}$ & $\begin{array}{l}63.00- \\
112.00\end{array}$ & 6.38 & $\begin{array}{l}6.58 \mathrm{E}- \\
06\end{array}$ \\
\hline Leaf temperature $\left({ }^{\circ} \mathrm{C}\right)$ & $\begin{array}{l}29.56 \pm \\
0.548\end{array}$ & $\begin{array}{l}27.94 \pm \\
0.385\end{array}$ & $\begin{array}{l}27.30- \\
30.55\end{array}$ & $\begin{array}{l}27.10- \\
28.70\end{array}$ & 5.79 & $\begin{array}{l}6.78 \mathrm{E} \\
25\end{array}$ \\
\hline Leaf rolling score & $\begin{array}{l}4.05 \pm \\
1.39\end{array}$ & - & $\begin{array}{l}1.11- \\
7.84\end{array}$ & - & - & - \\
\hline Leaf drying score & $\begin{array}{l}4.00 \pm \\
1.37\end{array}$ & - & $\begin{array}{l}1.17- \\
7.67\end{array}$ & - & - & - \\
\hline $\begin{array}{l}\text { Relative water content } \\
(\%)\end{array}$ & $\begin{array}{l}61.07 \pm \\
4.79\end{array}$ & $\begin{array}{l}78.89 \pm \\
3.89\end{array}$ & $\begin{array}{l}50.35- \\
72.98\end{array}$ & $\begin{array}{l}70.36- \\
86.26\end{array}$ & -22.58 & $\begin{array}{l}7.4 \mathrm{E}- \\
114\end{array}$ \\
\hline $\begin{array}{l}\text { Cell membrane stability } \\
\text { index }(\%)\end{array}$ & $\begin{array}{l}81.83 \pm \\
3.70\end{array}$ & - & $\begin{array}{l}75.53- \\
92.24\end{array}$ & - & - & - \\
\hline $\begin{array}{l}\text { Chlorophyll stability } \\
\text { index (\%) }\end{array}$ & $\begin{array}{l}82.11 \pm \\
3.85\end{array}$ & - & $\begin{array}{l}75.52- \\
92.85\end{array}$ & - & - & - \\
\hline Yield/plant (g) & $\begin{array}{l}8.40 \pm \\
1.57\end{array}$ & $\begin{array}{l}11.55 \pm \\
2.15\end{array}$ & $\begin{array}{l}6.06- \\
12.17\end{array}$ & $\begin{array}{l}7.94- \\
18.62\end{array}$ & -27.27 & $\begin{array}{l}1.81 \mathrm{E} \\
37\end{array}$ \\
\hline $\begin{array}{l}\text { Thousand grain weight } \\
\text { (g) }\end{array}$ & $\begin{array}{l}21.78 \pm \\
1.33\end{array}$ & $\begin{array}{l}22.66 \pm \\
1.35\end{array}$ & $\begin{array}{l}17.15- \\
24.00\end{array}$ & $\begin{array}{l}17.45- \\
24.95\end{array}$ & -3.88 & $\begin{array}{l}3.16 \mathrm{E} \\
08\end{array}$ \\
\hline $\begin{array}{l}\text { Spikelet fertility } \\
\text { percentage (\%) }\end{array}$ & $\begin{array}{l}61.04 \pm \\
4.39\end{array}$ & $\begin{array}{l}70.91 \pm \\
4.58\end{array}$ & $\begin{array}{l}50.47- \\
73.79\end{array}$ & $\begin{array}{l}61.12- \\
81.93\end{array}$ & -13.91 & $\begin{array}{l}1.24 \mathrm{E} \\
55\end{array}$ \\
\hline $\begin{array}{l}\text { Percentage relative } \\
\text { yield reduction }\end{array}$ & $\begin{array}{l}29.46 \pm \\
4.96\end{array}$ & - & $\begin{array}{l}17.91- \\
46.94\end{array}$ & - & - & - \\
\hline $\begin{array}{l}\text { Drought susceptibility } \\
\text { index }\end{array}$ & $\begin{array}{l}1.00 \pm \\
0.070\end{array}$ & - & $\begin{array}{l}0.75- \\
1.17\end{array}$ & - & - & - \\
\hline Soil moisture (\%) & - & - & $\begin{array}{l}10.75- \\
24.96\end{array}$ & - & - & - \\
\hline
\end{tabular}


Table 3

Descriptive statistics of plant morphological, physiological and root traits measured in diverse panel II in trials 3 and 4

\begin{tabular}{|c|c|c|c|c|c|}
\hline Traits & Year & Min & Maximum & Mean & SD \\
\hline \multirow[t]{3}{*}{ Plant Height (cm) } & 2011 & 62.90 & 174.40 & 110.36 & 24.67 \\
\hline & 2013 & 77.00 & 146.50 & 107.90 & 20.62 \\
\hline & Average & 74.84 & 146.75 & 108.93 & 17.78 \\
\hline \multirow[t]{3}{*}{ SPAD-Chlorophyll content (\%) } & 2011 & 26.66 & 44.88 & 36.72 & 3.72 \\
\hline & 2013 & 27.20 & 40.60 & 34.45 & 3.19 \\
\hline & Average & 29.22 & 41.03 & 35.62 & 2.50 \\
\hline \multirow[t]{3}{*}{ Shoot Biomass (g) } & 2011 & 4.08 & 29.24 & 19.26 & 7.32 \\
\hline & 2013 & 7.20 & 31.81 & 17.95 & 5.78 \\
\hline & Average & 8.81 & 28.77 & 18.60 & 4.75 \\
\hline \multirow[t]{3}{*}{ Root Length (cm) } & 2011 & 27.40 & 90.60 & 40.97 & 10.56 \\
\hline & 2013 & 35.60 & 96.00 & 51.61 & 11.59 \\
\hline & Average & 33.20 & 72.80 & 46.18 & 7.71 \\
\hline \multirow[t]{3}{*}{ Root Volume $\left(\mathrm{cm}^{3}\right)$} & 2011 & 8.40 & 74.00 & 31.25 & 13.96 \\
\hline & 2013 & 13.30 & 90.00 & 37.40 & 18.73 \\
\hline & Average & 14.50 & 78.00 & 34.20 & 12.54 \\
\hline \multirow[t]{3}{*}{ Root Biomass (g) } & 2011 & 4.08 & 29.24 & 12.56 & 6.27 \\
\hline & 2013 & 1.70 & 13.83 & 5.54 & 2.49 \\
\hline & Average & 4.08 & 18.19 & 9.04 & 3.25 \\
\hline
\end{tabular}


Table 4

Marker trait association identified with MLM analysis in diverse panel I phenotypic data measured under water stress

\begin{tabular}{|c|c|c|c|c|}
\hline Traits & Marker associated & Chromosome & $P$ value & $r^{2}$ value \\
\hline \multirow[t]{2}{*}{ Leaf temperature $\left({ }^{\circ} \mathrm{C}\right)$} & RM490 & 1 & 0.04996 & 0.05192 \\
\hline & RM259 & 1 & 0.02398 & 0.06945 \\
\hline \multirow[t]{2}{*}{ Chlorophyll stability index (\%) } & RM490 & 1 & 0.00736 & 0.07886 \\
\hline & RM259 & 1 & 0.00775 & 0.07778 \\
\hline \multirow[t]{2}{*}{ Yield per plant (g) } & RM259 & 1 & 0.02936 & 0.06402 \\
\hline & RM3825 & 1 & 0.02105 & 0.07209 \\
\hline Thousand grain weight (g) & RM5961 & 11 & 0.0312 & 0.05483 \\
\hline \multirow[t]{2}{*}{ Spikelet fertility (\%) } & RM259 & 1 & 0.0098 & 0.07782 \\
\hline & RM1031 & 6 & 0.04376 & 0.04657 \\
\hline Leaf rolling score & RM1026 & 9 & 0.00386 & 0.10547 \\
\hline \multirow[t]{2}{*}{ Leaf drying score } & RM259 & 1 & 0.03024 & 0.05067 \\
\hline & RM1026 & 9 & 0.01671 & 0.06224 \\
\hline \multirow[t]{2}{*}{ Relative yield reduction (\%) } & RM5633 & 4 & 0.04017 & 0.05729 \\
\hline & RM1130 & 6 & 0.01309 & 0.08492 \\
\hline \multirow[t]{2}{*}{ Drought susceptibility index } & RM5633 & 4 & 0.04094 & 0.05682 \\
\hline & RM1130 & 6 & 0.01345 & 0.08419 \\
\hline
\end{tabular}


Table 5

Marker trait association identified with MLM analysis in diverse panel II phenotypic data measured under water stress

\begin{tabular}{|c|c|c|c|c|}
\hline Trait & $\begin{array}{l}\text { Marker } \\
\text { associated }\end{array}$ & $\begin{array}{l}\text { Chromosome } \\
\text { number }\end{array}$ & $p$-value & $r^{2}$ value \\
\hline \multirow[t]{2}{*}{ Plant Height (cm) } & RM1032 & 1 & 0.02369 & 0.06739 \\
\hline & RM5961 & 11 & 0.0272 & 0.06414 \\
\hline \multirow[t]{3}{*}{ Root Length (cm) } & RM1048 & 7 & 0.01914 & 0.07245 \\
\hline & RM1019 & 8 & 0.02792 & 0.06353 \\
\hline & RM1032 & 1 & 0.03786 & 0.05648 \\
\hline \multirow[t]{3}{*}{ Root Volume $\left(\mathrm{cm}^{3}\right)$} & RM5715 & 12 & 0.01405 & 0.07992 \\
\hline & RM1178 & 2 & 0.01452 & 0.07911 \\
\hline & RM246 & 1 & 0.03366 & 0.05918 \\
\hline Root dry weight (g) & RM5923 & 11 & 0.04139 & 0.05444 \\
\hline \multirow[t]{2}{*}{ Shoot dry weight (g) } & RM1178 & 2 & 0.00507 & 0.10531 \\
\hline & RM474 & 10 & 0.03569 & 0.05783 \\
\hline \multirow[t]{2}{*}{ SCMR- Chlorophyll content (\%) } & RM5633 & 4 & 0.03022 & 0.06169 \\
\hline & RM1178 & 2 & 0.03806 & 0.05636 \\
\hline \multirow[t]{3}{*}{ Chlorophyll content } & RM1026 & 9 & 0.01678 & 0.07561 \\
\hline & RM259 & 1 & 0.03092 & 0.06115 \\
\hline & RM5633 & 4 & 0.04763 & 0.05126 \\
\hline \multirow{2}{*}{$\begin{array}{l}\text { Carbon isotope discrimination } \\
\left(\Delta^{13} C\right) \text { ratio }\end{array}$} & RM5961 & 11 & 0.01652 & 0.07598 \\
\hline & RM1019 & 8 & 0.01918 & 0.07241 \\
\hline \multirow[t]{3}{*}{ Specific leaf area $\left(\mathrm{cm}^{2}\right)$} & RM5961 & 11 & 0.01369 & 0.08054 \\
\hline & RM5633 & 4 & 0.02136 & 0.06984 \\
\hline & RM283 & 1 & 0.04124 & 0.05453 \\
\hline
\end{tabular}


Table 6

Genes underlying common genomic regions identified in marker trait association in diverse panel I

\begin{tabular}{|c|c|c|c|c|c|}
\hline \multirow[t]{2}{*}{ Marker } & \multirow[t]{2}{*}{ Chr. } & \multirow[t]{2}{*}{$\begin{array}{l}\text { Physical position } \\
(\mathrm{Mb})^{\#}\end{array}$} & \multicolumn{2}{|l|}{ Traits associated } & \multirow[t]{2}{*}{$\begin{array}{l}\text { Genes within } \\
\text { confidence interval \# }\end{array}$} \\
\hline & & & GLM & MLM & \\
\hline \multirow[t]{2}{*}{ RM259 } & 1 & $7446642 . .7446813$ & $\begin{array}{l}\text { CSI, SF, LD, LR, } \\
\text { RWC }\end{array}$ & $\begin{array}{l}\text { LT, CSI, SF, } \\
\text { LD, Yield } \\
\text { per plant }\end{array}$ & $\begin{array}{l}\text { Phosphatidylinositol } \\
\text { 3- and 4-kinase } \\
\text { family protein }\end{array}$ \\
\hline & & & & & LOC_Os01g13360 \\
\hline \multirow[t]{4}{*}{ RM490 } & 1 & $6677153 . .6677249$ & CSI, CMS & LT, CSI & peptidase C45 \\
\hline & & & & & LOC_Os01g12230 \\
\hline & & & & & Hypothetical protein \\
\hline & & & & & LOC_Os01g12240 \\
\hline \multirow[t]{4}{*}{ RM3825 } & 1 & $36471204 . .36471354$ & LT, RWC, CMS, CSI, & Yield per & Ras-related protein \\
\hline & & & per plant & & LOC_Os01g62950 \\
\hline & & & & & Hypothetical protein \\
\hline & & & & & LOC_Os01g62960 \\
\hline \multirow[t]{4}{*}{ RM5633 } & 4 & $13084092 . .13084302$ & $\mathrm{PH}, \mathrm{DFF}$ & DSI, RYR & $\begin{array}{l}\text { Retrotransposon } \\
\text { protein }\end{array}$ \\
\hline & & & & & LOC_Os04g23030 \\
\hline & & & & & Expressed protein \\
\hline & & & & & LOC_Os04g23040 \\
\hline \multirow[t]{2}{*}{ RM1130 } & 6 & $27284878 . .27285006$ & - & DSI, RYR & DNA binding protein \\
\hline & & & & & LOC_Os06g45110 \\
\hline \multirow[t]{2}{*}{ RM1031 } & 6 & $31083106 . .31089543$ & CMS, RWC & SF & Expressed protein \\
\hline & & & & & LOC_Os06g51330 \\
\hline \multirow[t]{2}{*}{ RM1026 } & 9 & $22605659 . .22605822$ & $\mathrm{PH}$ & LR, LD & $\begin{array}{l}\text { CTR1-like protein } \\
\text { kinase }\end{array}$ \\
\hline & & & & & LOC_Os09g39320 \\
\hline
\end{tabular}

\# The physical position of SSR markers and genes underlying were obtained from www.ricebase.org. [Abbreviations: CMS- Chlorophyll Membrane Stability; CSI-Chlorophyll Stability Index; DSI- Drought susceptibility index; LD- Leaf Drying; LR-Leaf Rolling; LT- Leaf Temperature; RWC- Relative Water Content; RYR- Relative Yield Ratio; SF-Spikelet Fertility; 1000 GW- Thousand grain weight] 


\begin{tabular}{|c|c|c|c|c|c|}
\hline \multirow[t]{2}{*}{ Marker } & \multirow[t]{2}{*}{ Chr. } & \multirow{2}{*}{$\begin{array}{l}\text { Physical position } \\
(\mathrm{Mb}){ }^{\#}\end{array}$} & \multicolumn{2}{|c|}{ Traits associated } & \multirow{2}{*}{$\begin{array}{l}\text { Genes within } \\
\text { confidence interval }\end{array}$} \\
\hline & & & GLM & MLM & \\
\hline \multirow[t]{2}{*}{ RM5961 } & 11 & $19926656 . .19926784$ & - & $1000 \mathrm{GW}$ & Hypothetical protein \\
\hline & & & & & LOC_Os11g34070 \\
\hline \multicolumn{6}{|c|}{$\begin{array}{l}\text { \# The physical position of SSR markers and genes underlying were obtained from www.ricebase.org. } \\
\text { [Abbreviations: CMS- Chlorophyll Membrane Stability; CSI-Chlorophyll Stability Index; DSI- Drought } \\
\text { susceptibility index; LD- Leaf Drying; LR-Leaf Rolling; LT- Leaf Temperature; RWC- Relative Water } \\
\text { Content; RYR- Relative Yield Ratio; SF-Spikelet Fertility; } 1000 \mathrm{GW} \text {-Thousand grain weight] }\end{array}$} \\
\hline
\end{tabular}


Table 7

List of genes underlying genomic regions identified in both GLM and MLM approaches with association analysis in diverse panel II

\begin{tabular}{|c|c|c|c|c|c|}
\hline \multirow[t]{2}{*}{ Marker } & \multirow[t]{2}{*}{ Chr. } & \multirow{2}{*}{$\begin{array}{l}\text { Physical } \\
\text { position (Mb) } \\
\#\end{array}$} & \multicolumn{2}{|c|}{ Traits associated } & \multirow[t]{2}{*}{ Genes within confidence interval \# } \\
\hline & & & GLM & MLM & \\
\hline RM259 & 1 & $\begin{array}{l}7446642- \\
7446813\end{array}$ & $\mathrm{Chl}$ & $\mathrm{Chl}$ & $\begin{array}{l}\text { Phosphatidylinositol 3-and 4-kinase family } \\
\text { protein (LOC_Os01g13360) }\end{array}$ \\
\hline \multirow[t]{2}{*}{ RM1032 } & \multirow[t]{2}{*}{1} & \multirow{2}{*}{$\begin{array}{l}9318464- \\
9318612\end{array}$} & \multirow[t]{2}{*}{$\mathrm{PH}, \mathrm{RL}$} & \multirow[t]{2}{*}{$\mathrm{PH}, \mathrm{RL}$} & NB-ARC domain (LOC_Os01g16400) \\
\hline & & & & & Actin (LOC_Os01g16414) \\
\hline RM246 & 1 & $\begin{array}{l}27336221- \\
27336333\end{array}$ & SPAD & $\mathrm{RV}$ & $\begin{array}{l}\text { CS domain containing protein (LOC_ } \\
\text { Os01g47770) }\end{array}$ \\
\hline RM1178 & 2 & $\begin{array}{l}14020245- \\
14020356\end{array}$ & $\begin{array}{l}\text { RV, } \\
\text { SDW, } \\
\text { CT }\end{array}$ & $\begin{array}{l}\text { RV, } \\
\text { SDW, } \\
\text { SPAD }\end{array}$ & Expressed protein (LOC_Os02g24205) \\
\hline \multirow[t]{2}{*}{ RM5633 } & \multirow[t]{2}{*}{4} & \multirow[t]{2}{*}{$\begin{array}{l}13084092- \\
13084302\end{array}$} & \multirow[t]{2}{*}{$R L, R V$} & \multirow{2}{*}{$\begin{array}{l}\text { SPAD, } \\
\text { Chl, } \\
\text { SLA }\end{array}$} & $\begin{array}{l}\text { Retrotransposon protein } \\
\text { (LOC_Os04g23030) }\end{array}$ \\
\hline & & & & & Expressed protein (LOC_Os04g23040) \\
\hline RM1048 & 7 & $\begin{array}{l}20165312- \\
20165449\end{array}$ & $\mathrm{RL}, \mathrm{CT}$ & $\mathrm{RL}$ & NB-ARC domain (LOC_Os07g33730 \\
\hline RM1019 & 8 & $\begin{array}{l}202331- \\
202477\end{array}$ & $\begin{array}{l}\text { RL, } \\
\text { SPAD, } \\
\text { Chl }\end{array}$ & $\mathrm{RL}, \mathrm{CID}$ & $\begin{array}{l}\text { Broad Complex BTB domain } \\
\text { (LOC_Os08g01320) }\end{array}$ \\
\hline RM1026 & 9 & $\begin{array}{l}22605659- \\
22605822\end{array}$ & $\begin{array}{l}\mathrm{RL}, \mathrm{RV}, \\
\mathrm{Chl}\end{array}$ & $\mathrm{Chl}$ & $\begin{array}{l}\text { CTR1-like protein kinase } \\
\text { (LOC_Os09g39320) }\end{array}$ \\
\hline RM5961 & 11 & $\begin{array}{l}19926656- \\
19926784\end{array}$ & $\mathrm{Chl}$ & $\begin{array}{l}\text { PH, CID, } \\
\text { SLA }\end{array}$ & Hypothetical protein (LOC_Os11g34070) \\
\hline \multirow[t]{2}{*}{ RM5715 } & \multirow[t]{2}{*}{12} & \multirow{2}{*}{$\begin{array}{l}25034080- \\
25034280\end{array}$} & \multirow{2}{*}{$\begin{array}{l}\text { RV, RL, } \\
\text { Chl }\end{array}$} & \multirow[t]{2}{*}{ RV } & Biotin-protein ligase (LOC_Os12g40450) \\
\hline & & & & & $\begin{array}{l}\text { C3HC4 type domain protein } \\
\text { (LOC_Os } 12 \mathrm{~g} 40460)\end{array}$ \\
\hline $\begin{array}{l}\text { \# The ph } \\
\text { [Abbrevi } \\
\text { Chlorop } \\
\text { CID-Cark }\end{array}$ & & $\begin{array}{l}\text { ion of SSR } \\
\text { Chlorophyll } \\
(\%) ; \text { SDW-S }\end{array}$ & ers and & les unde & $\begin{array}{l}\text { ying were obtained from www.ricebase.org. } \\
\text { RL-Root length; RV-Root Volume; SPAD- } \\
\text { py Temperature; SLA-Specific Leaf Area; }\end{array}$ \\
\hline
\end{tabular}


Table 8

List of haplotype variation identified in genomic regions detected in this study with genome sequence information on 93 rice land races.

\begin{tabular}{|c|c|c|c|c|c|c|}
\hline $\begin{array}{l}\text { Chr. (Physical } \\
\text { position in } \mathrm{Mb}^{\#} \text { ) }\end{array}$ & $\begin{array}{l}\text { Marker } \\
\text { located }\end{array}$ & $\begin{array}{l}\text { Reference } \\
\text { Allele }\end{array}$ & $\begin{array}{l}\text { Alt } \\
\text { Allele }\end{array}$ & $\begin{array}{l}\text { Position } \\
\text { (Mb) }\end{array}$ & SNP type & $\begin{array}{l}\text { Traits associated } \\
\text { in MLM } \\
\text { approach }\end{array}$ \\
\hline \multirow{3}{*}{$\begin{array}{l}\text { CHR1 (9318264- } \\
\text { 9318812) }\end{array}$} & \multirow[t]{3}{*}{ RM1032 } & $\mathrm{T}$ & $\mathrm{C}$ & 9318278 & \multirow{3}{*}{$\begin{array}{l}\text { Up-stream } \\
\text { gene } \\
\text { variant } \\
\text { Intergenic } \\
\text { region } \\
\text { variant }\end{array}$} & \multirow[t]{3}{*}{ PH, RL (Panel II) } \\
\hline & & C & $A$ & 9318295 & & \\
\hline & & & & & & \\
\hline \multirow{4}{*}{$\begin{array}{l}\text { CHR4 } \\
\text { (13083892- } \\
13084502)\end{array}$} & \multirow[t]{4}{*}{ RM5633 } & $\mathrm{T}$ & C & 13083944 & \multirow{2}{*}{$\begin{array}{l}\text { Intergenic } \\
\text { region } \\
\text { variant }\end{array}$} & \multirow{3}{*}{$\begin{array}{l}\text { DSI, RYR (Panel } \\
\text { I) } \\
\text { SPAD, Chl, SLA } \\
\text { (Panel II) }\end{array}$} \\
\hline & & A & $\mathrm{T}$ & 13083963 & & \\
\hline & & \multirow[t]{2}{*}{ A } & \multirow[t]{2}{*}{ C } & \multirow[t]{2}{*}{13084032} & $\begin{array}{l}\text { Intergenic } \\
\text { region } \\
\text { variant }\end{array}$ & \\
\hline & & & & & $\begin{array}{l}\text { Intergenic } \\
\text { region } \\
\text { variant }\end{array}$ & \\
\hline $\begin{array}{l}\text { CHR6 } \\
\text { (31082906- } \\
31089743)\end{array}$ & RM1031 & G & A & 31089179 & $\begin{array}{l}\text { Down- } \\
\text { stream } \\
\text { gene } \\
\text { variant }\end{array}$ & SF (Panel I) \\
\hline \multirow{3}{*}{$\begin{array}{l}\text { CHR11 } \\
\text { (19926456- } \\
\text { 19926984) }\end{array}$} & \multirow[t]{3}{*}{ RM5961 } & $\mathrm{T}$ & G & 19926506 & \multirow{2}{*}{$\begin{array}{l}\text { Down- } \\
\text { stream } \\
\text { gene } \\
\text { variant }\end{array}$} & \multirow{3}{*}{$\begin{array}{l}1000 \text { GW (Panel } \\
\text { I) } \\
\text { PH, CID, SLA } \\
\text { (Panel II) }\end{array}$} \\
\hline & & A & G & 19926513 & & \\
\hline & & & & & $\begin{array}{l}\text { Down- } \\
\text { stream } \\
\text { gene } \\
\text { variant }\end{array}$ & \\
\hline $\begin{array}{l}\text { \# The physical pos } \\
\text { [Abbreviations: Ch } \\
\text { susceptibility inde } \\
\text { content (\%); SLA- }\end{array}$ & $\begin{array}{l}\text { on of SSR } \\
\text { hlorophyl } \\
\text { H-Plant } 1 \\
\text { cific Leaf }\end{array}$ & $\begin{array}{l}\text { arkers and } \\
\text { nntent; CID-( } \\
\text { ht; RL-Root }\end{array}$ & $\begin{array}{l}\text { enes u } \\
\text { arbon } \\
\text { ength; }\end{array}$ & $\begin{array}{l}\text { lerlying we } \\
\text { tope Discr } \\
\text { YR- Relative } \\
\text { y; } 1000 \mathrm{GV}\end{array}$ & $\begin{array}{l}\text { intained fro } \\
\text { ination; DSI } \\
\text { ield Ratio; } \mathrm{S} \\
\text { housand g }\end{array}$ & $\begin{array}{l}\text { ww.ricebase.org. } \\
\text { ught } \\
\text {--Chlorophyll } \\
\text { weight] }\end{array}$ \\
\hline
\end{tabular}


Table 9

List of SNP variation identified in rice landraces for potential use as molecular markers in drought rice breeding

\begin{tabular}{|c|c|c|c|c|c|}
\hline $\begin{array}{l}\text { Trait Association } \\
\text { (Marker linked) }\end{array}$ & $\begin{array}{l}\text { Chr. } \\
\text { Phys. } \\
\text { position } \\
\text { (Mb) \# }\end{array}$ & $\begin{array}{l}\text { Elite } \\
\text { allele }\end{array}$ & $\begin{array}{l}\text { Position } \\
\text { (Mb) }\end{array}$ & $\begin{array}{l}\text { Landrace } \\
\text { allele }\end{array}$ & $\begin{array}{l}\text { Landrace allele present } \\
\text { in }\end{array}$ \\
\hline $\mathrm{PH} / \mathrm{RL}$ & CHR1 & $\mathrm{C}$ & 9318278 & $\mathrm{~T}$ & \multirow[t]{2}{*}{ PTB 8} \\
\hline (RM1032) & $\begin{array}{l}9318264- \\
9318812\end{array}$ & $A$ & 9318295 & C & \\
\hline SPAD/ Chl/ SLA & CHR4 & C & 13083944 & $\mathrm{~N}$ & \multirow{3}{*}{$\begin{array}{l}\text { All four accessions: } \\
\text { PTB8, Kalladiyar, } \\
\text { Gandhakashala, } \\
\text { Jeerakashala }\end{array}$} \\
\hline \multirow[t]{2}{*}{ (RM5633) } & \multirow{2}{*}{$\begin{array}{l}13083892- \\
13084502\end{array}$} & $\mathrm{~T}$ & 13083963 & $\mathrm{~N}$ & \\
\hline & & C & 13084032 & $\mathrm{~N}$ & \\
\hline $\mathrm{PH} / \mathrm{CID} / \mathrm{SLA} / 1000 \mathrm{GW}$ & CHR11 & $\mathrm{T}$ & 19926506 & $\mathrm{~N}$ & PTB51, РTB25 \\
\hline \multirow[t]{5}{*}{ (RM5961) } & \multirow{5}{*}{$\begin{array}{l}19926456 \\
-1926984\end{array}$} & & & $\mathrm{~K}$ & Gandhakashala \\
\hline & & & & G & PTB26 \\
\hline & & $A$ & 19926513 & $\mathrm{~N}$ & PTB51, РTB25 \\
\hline & & & & $\mathrm{R}$ & Gandhakashala \\
\hline & & & & G & PTB26 \\
\hline SF & CHR6 & $\mathrm{R}$ & 31089179 & A & Kalladiyar \\
\hline \multirow[t]{3}{*}{ RM1031 } & \multirow{3}{*}{$\begin{array}{l}31082906- \\
31089743\end{array}$} & & & G & \multirow{2}{*}{$\begin{array}{l}\text { PTB2, 10, } 25 \text { and 26, } \\
\text { Gandhakashala, } \\
\text { Jeerakashala }\end{array}$} \\
\hline & & & & $\mathrm{R}$ & \\
\hline & & & & & PTB8, Chomala \\
\hline
\end{tabular}

\section{Figures}




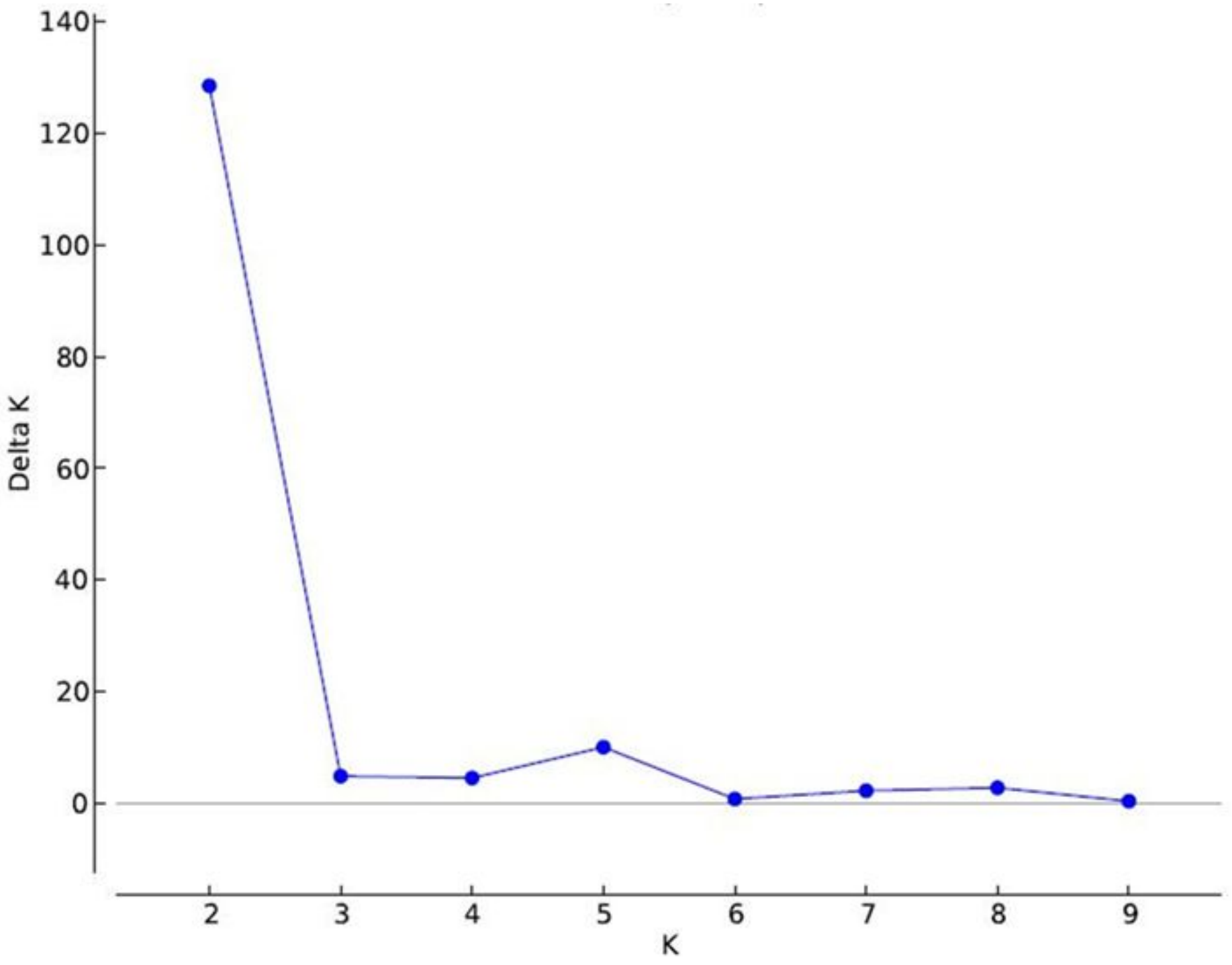

Figure 1

Estimates of subpopulations analysis of 81 diverse rice panels revealed 2 sub population using delta Kvalues with STRUCTURE program 


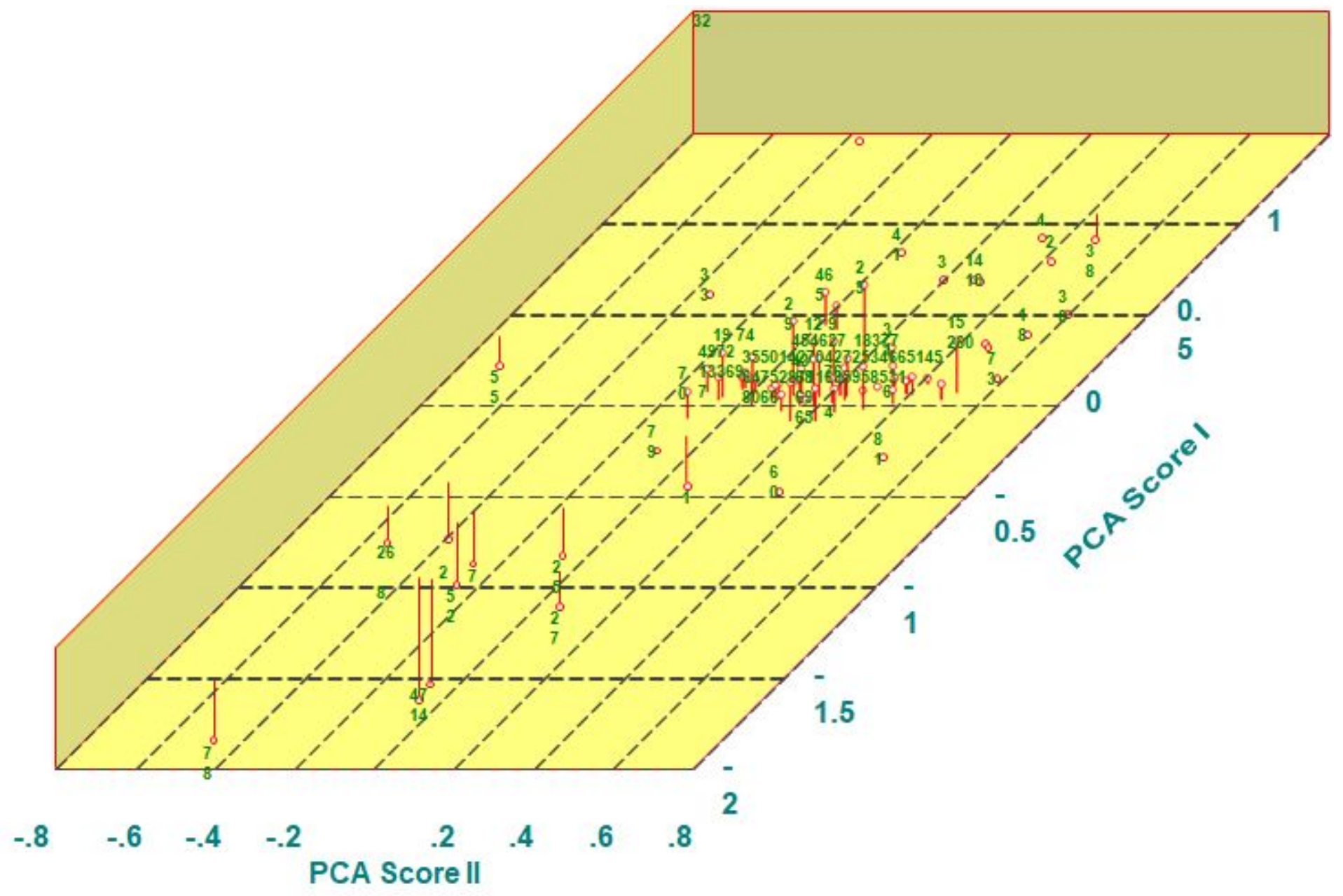

Figure 1

Three dimensional of Principal Co-ordinate analysis of 81 rice diverse panel II genotyped with 100 Simple Sequence Repeat markers

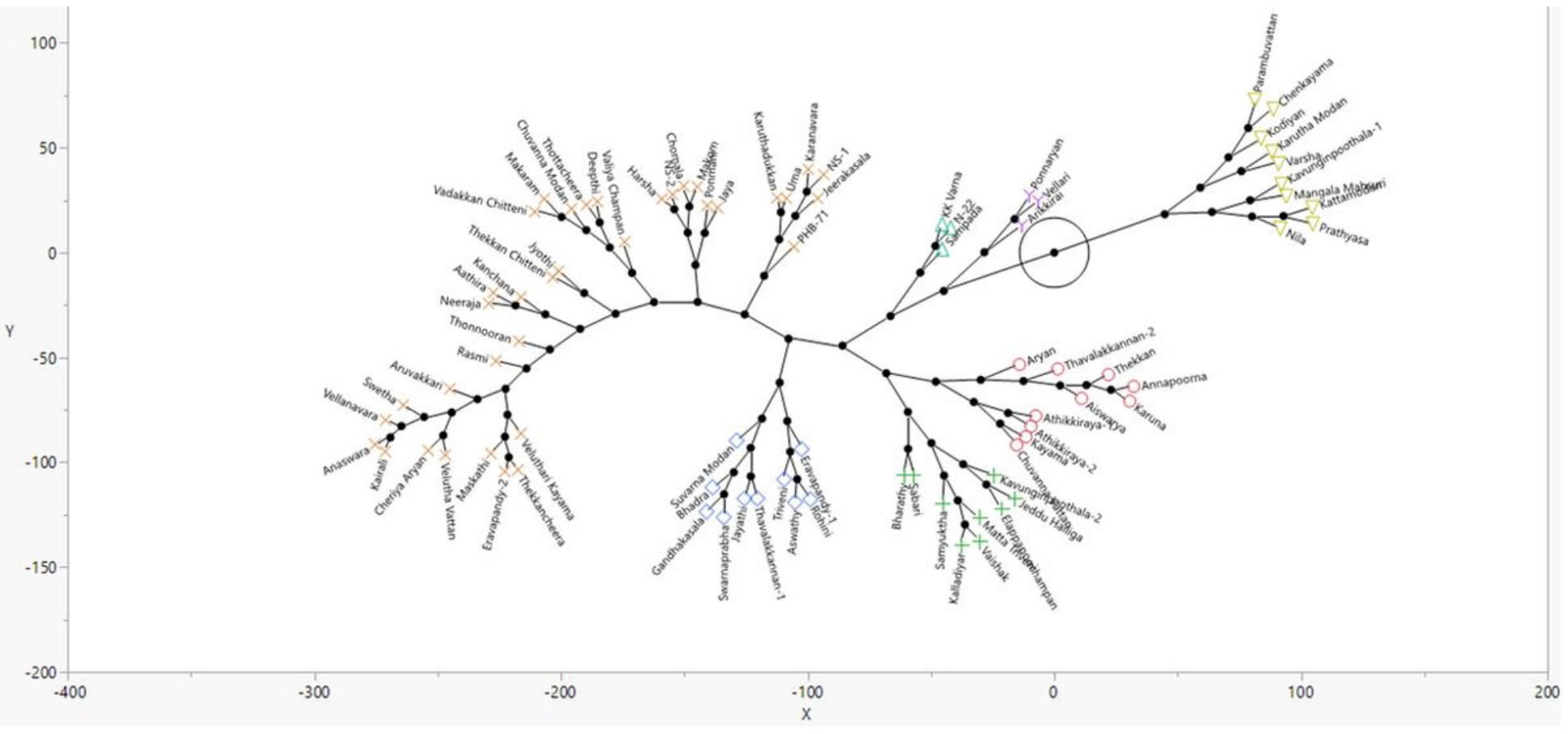


Figure 1

Constellation plot to show genetic relatedness among 81 diverse rice of Panel II based on hierarchial clustering analysis

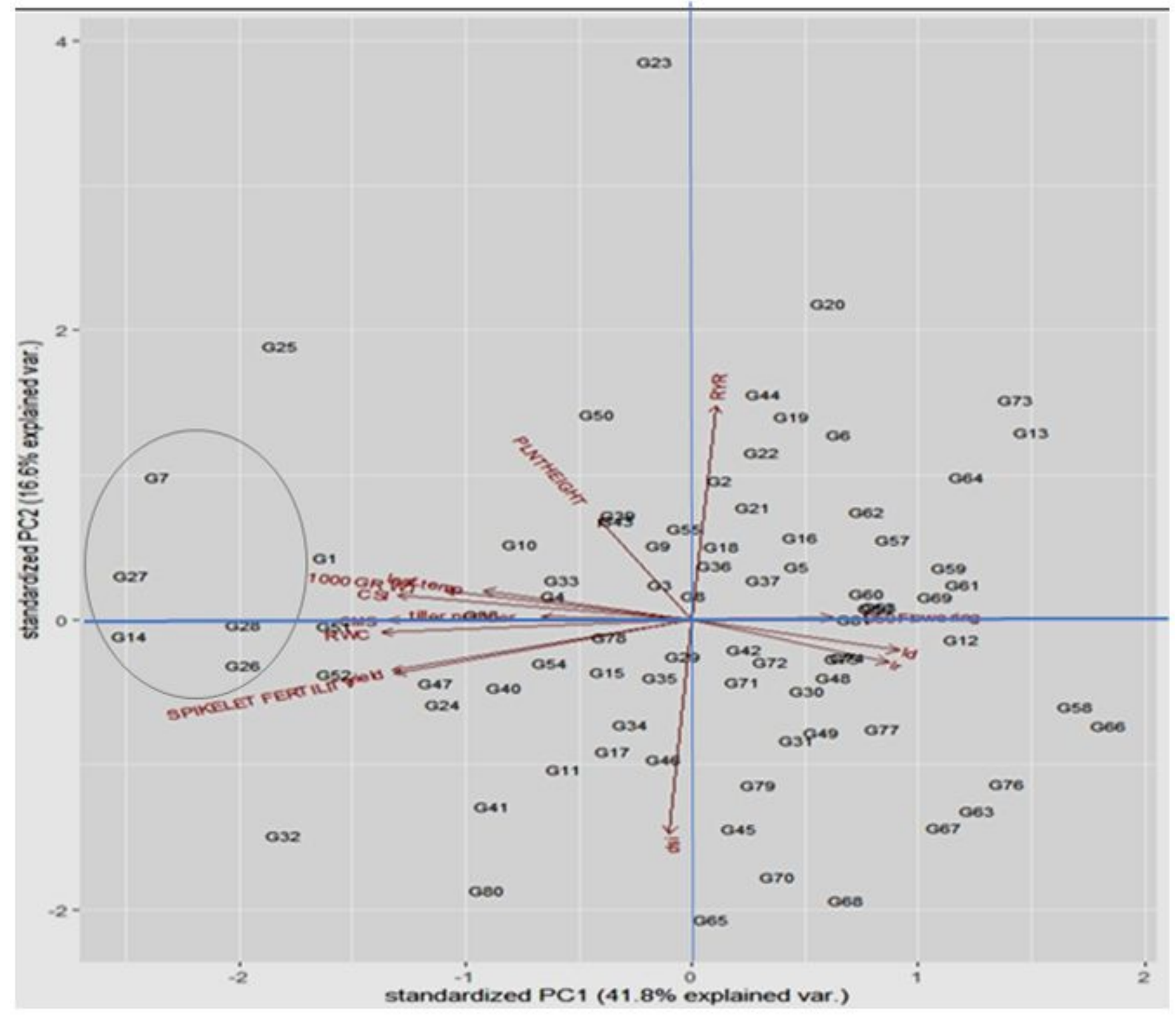

\section{Figure 1}

Genotype-by-trait-biplot analysis of 81 rice genotypes for two principal components under water stress. The encircled area depicted drought tolerant genotypes (G7-Parambuvattan (Ptb7); G14Kavunginpoothala (Ptb15); G26-Kattamodan (Ptb28); G27-KaruthaModan (Ptb29); G28-ChuvannaModan (Ptb30). 

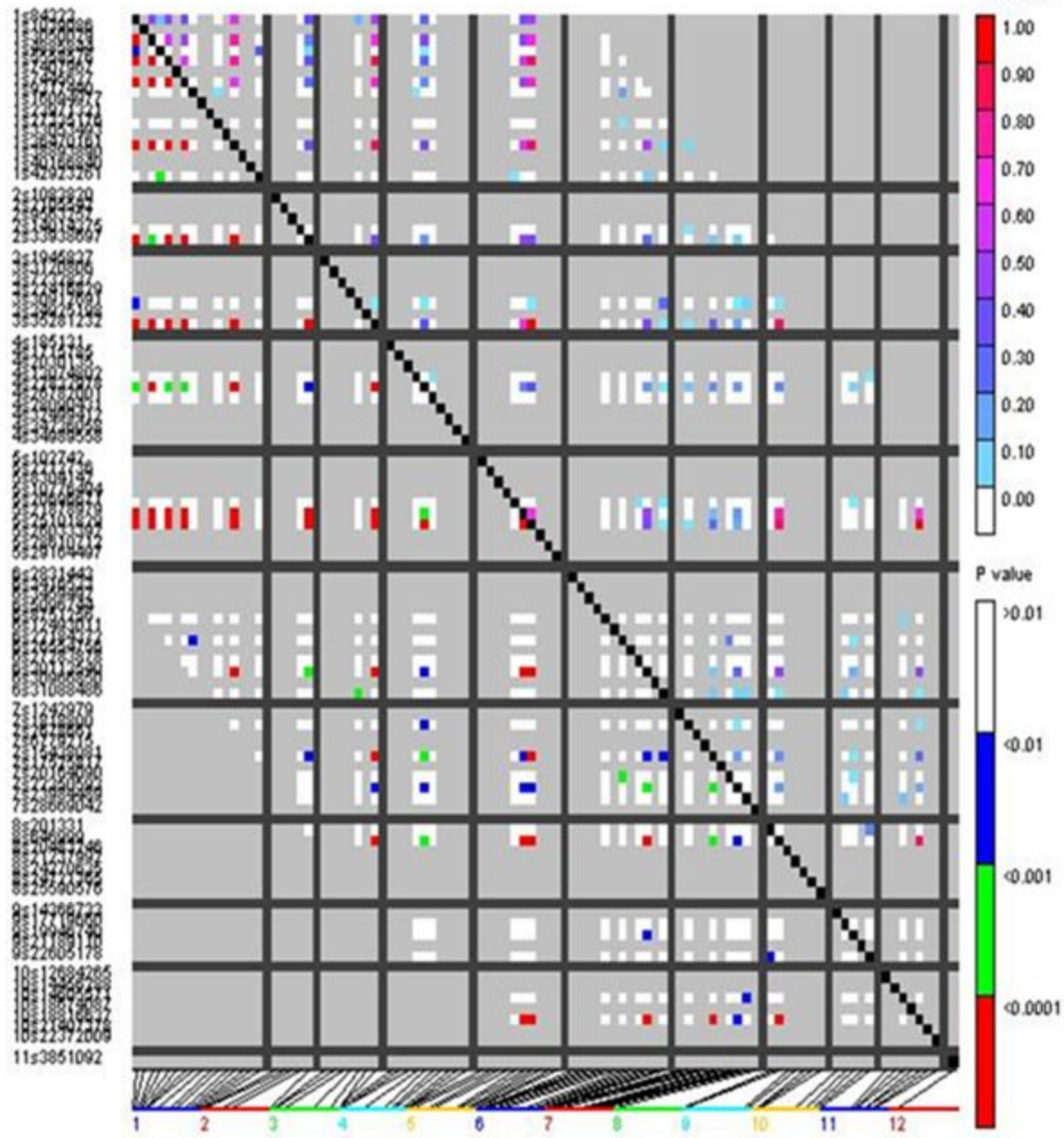

Figure 1

LD plot for a pair-wise SSR marker across rice genome used in genotyping diverse panel. Correlated markers were colour coded based on scales provided. Each pixel above the diagonal represents the $r 2$ value and P-value of corresponding markers. 
Level of expression

MEDIUM (=IQR) HIGH

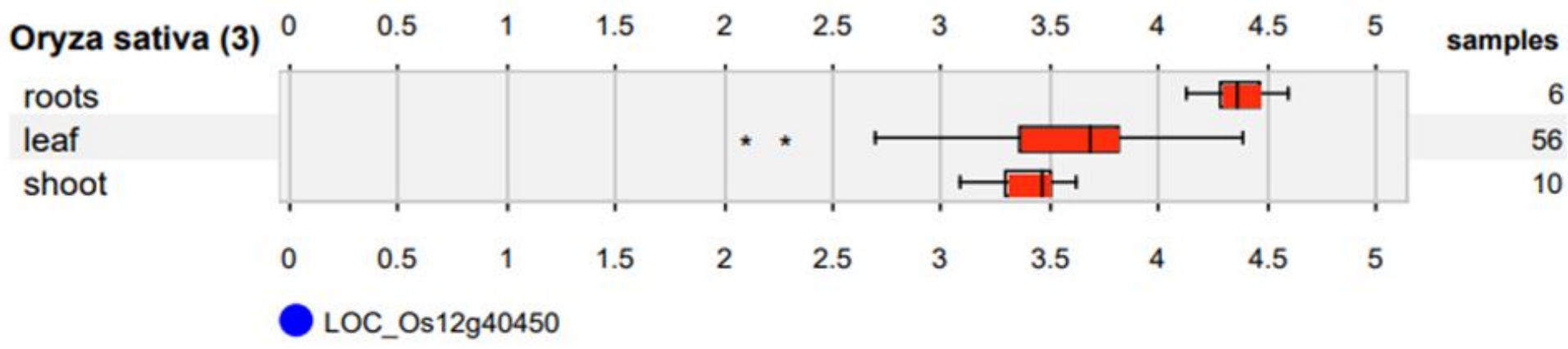

Level of expression
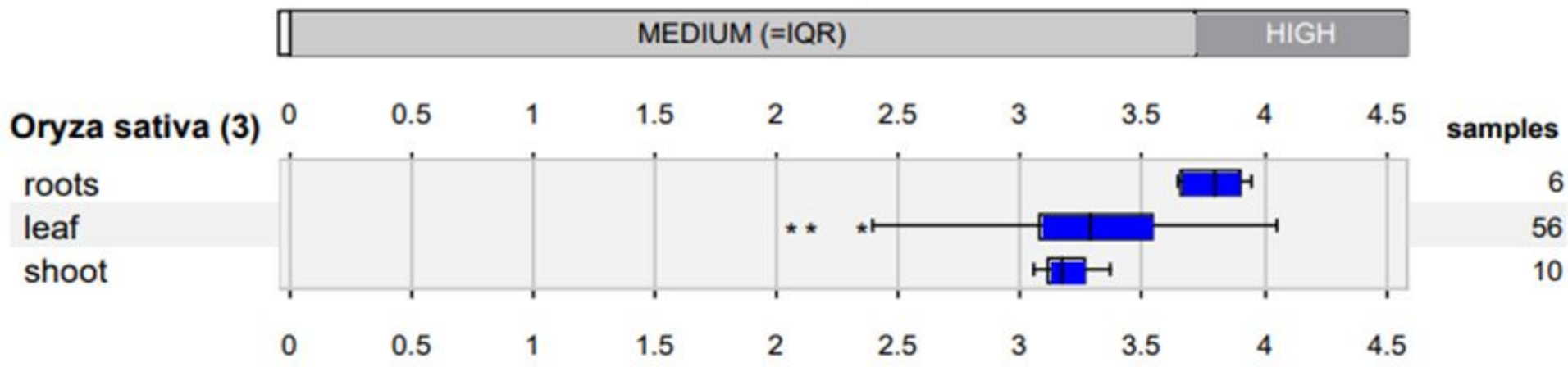

Figure 1

Expression profiling of candidate genes underlying root architectural and chlorophyll content on chromosome 9 and 12 identified in this study from drought stress RNA transcriptome data within Genevestigator software

\section{Supplementary Files}

This is a list of supplementary files associated with this preprint. Click to download.

- SupplementaryTables.doc

- SupplementaryFigure1.pptx 